\title{
Recent developments of novel matrices and on-tissue chemical derivatization reagents for MALDI-MSI
}

\author{
Qiuqin Zhou ${ }^{1}$ - Annabelle Fülöp ${ }^{1} \cdot$ Carsten Hopf $^{1}$ (D)
}

Received: 13 August 2020 / Revised: 17 October 2020 / Accepted: 22 October 2020 / Published online: 19 November 2020

(C) The Author(s) 2020

\begin{abstract}
Matrix-assisted laser desorption/ionization mass spectrometry imaging (MALDI-MSI) is a fast-growing technique for visualization of the spatial distribution of the small molecular and macromolecular biomolecules in tissue sections. Challenges in MALDI-MSI, such as poor sensitivity for some classes of molecules or limited specificity, for instance resulting from the presence of isobaric molecules or limited resolving power of the instrument, have encouraged the MSI scientific community to improve MALDI-MSI sample preparation workflows with innovations in chemistry. Recent developments of novel small organic MALDI matrices play a part in the improvement of image quality and the expansion of the application areas of MALDI-MSI. This includes rationally designed/ synthesized as well as commercially available small organic molecules whose superior matrix properties in comparison with common matrices have only recently been discovered. Furthermore, on-tissue chemical derivatization (OTCD) processes get more focused attention, because of their advantages for localization of poorly ionizable metabolites and their, in several cases, more specific imaging of metabolites in tissue sections. This review will provide an overview about the latest developments of novel small organic matrices and on-tissue chemical derivatization reagents for MALDI-MSI.
\end{abstract}

Keywords MALDI-MSI $\cdot$ MALDI matrix $\cdot$ MALDI imaging $\cdot$ On-tissue chemical derivatization $\cdot$ Tissue preparation

\section{Introduction}

Matrix-assisted laser desorption/ionization (MALDI) time-offlight (TOF) mass spectrometry imaging (MSI) can provide unparalleled insight into the spatial distribution of proteins [1], peptides [2], small molecules [3], lipids [4], glycans [5], and drugs [6] in tissue sections. The fast-evolving MALDI-MSI technique has been successfully applied in basic research, in pharmaceutical research [6], plant biology [7], food analysis [8], microbiology [9], and in clinical biomarker discovery [10]. In short, typical MALDI-MSI workflows contain the following three steps: tissue preparation, data acquisition, and data analysis. The "4S-criteria" for a desirable MSI experiment [6], namely speed, specificity, spatial resolution, and

Published in the topical collection Mass Spectrometry Imaging 2.0 with guest editors Shane R. Ellis and Tiffany Porta Siegel.

Carsten Hopf

c.hopf@hs-mannheim.de

1 Center for Mass Spectrometry and Optical Spectroscopy (CeMOS), Mannheim University of Applied Sciences, Paul-Wittsack-Str. 10, 68163 Mannheim, Germany sensitivity, often cannot be achieved together, and compromises are required for MALDI-MSI methods. Although developments of mass spectrometer hardware have a great impact on the performance of MALDI-MSI, proper tissue preparation [11-14] is key for high-quality data acquisition. During tissue preparation, it is essential to preserve the fidelity of analytes and prevent their spatial dislocation in tissue. Additionally, time consumption for tissue preparation should stay within an acceptable range, in most cases several hours. Important steps for tissue preparation are illustrated in Fig. 1.

Different workflows from tissue collection to data acquisition can be followed for tissue preparation. Depending on tissue type, targeted analyte species and on experimental goals, washes, on-tissue enzymatic digestion (OTED), ontissue chemical derivatization (OTCD), and application of internal standard are options in addition to the main experimental workflow (Fig. 1) [12, 15, 16]. Initially, procedures for collecting, storing, embedding, and sectioning of tissue samples have great influence on the resulting quality and need to be standardized for the same types of tissue. Later, wash protocols can be applied to remove interfering endogenous compounds, which compete with analytes during ionization and cause ion suppression effects. For example, wash protocols 


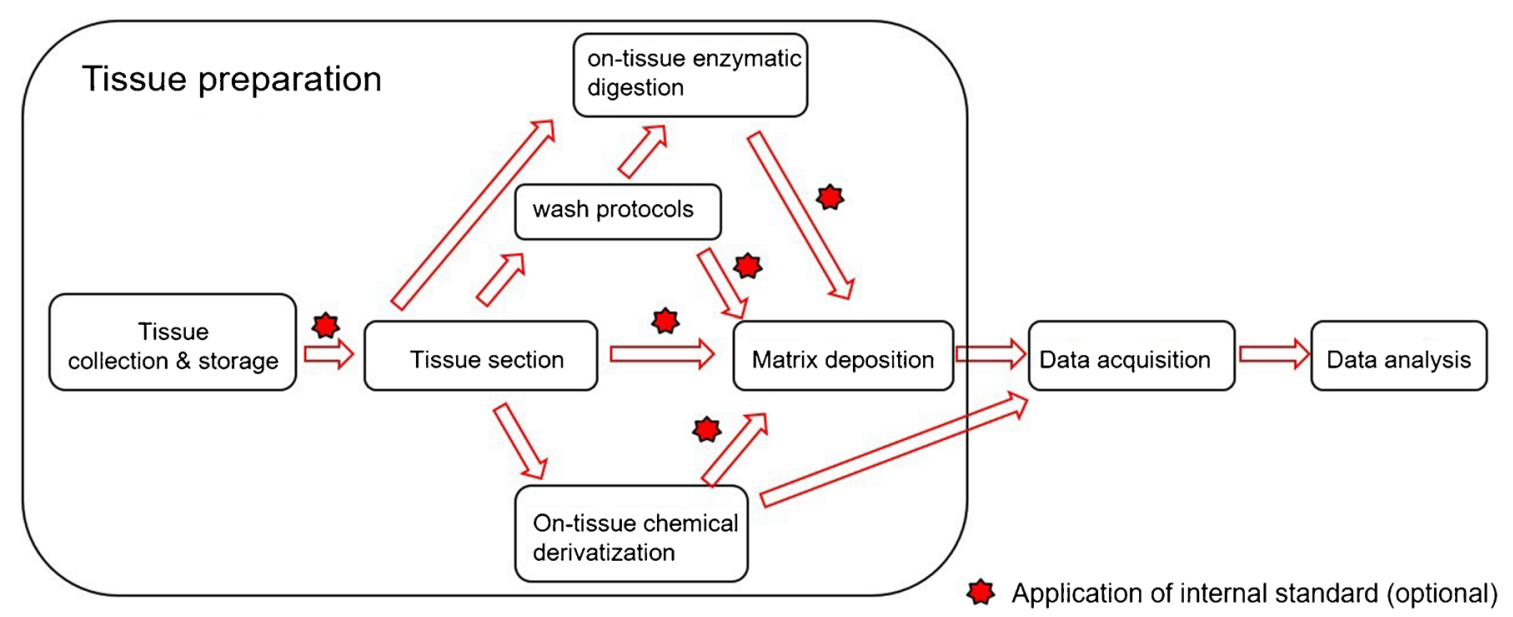

Fig. 1 Schema of experimental workflow for MALDI-MSI with highlighted important steps for tissue preparation

are indispensable for imaging of peptides and proteins in tissue sections to get rid of physiological salts and abundant lipids. Furthermore, wash protocols can also be used to enhance the subsequent ionization or extraction of the analytes into the matrix layer [17-19]. OTED belongs to often-used strategies for identification and visualization of proteins [2] and glycans [5]. Finally, before starting data acquisition, the matrix needs to be applied homogenously except that reagents used in the optional OTCD step can comply the requirement and replace of the additional matrix application. Choosing a suitable matrix and a suitable deposition method can avoid missing analytes or other time-consuming tissue preparation steps $[13,20]$. Aiming at improvement of detection specificity and enhancement of detection sensitivity in some approaches, OTCD has been specially developed for small molecule analytes [21]. To compensate ion suppression effects in heterogeneous tissue sections, internal standard can be used for normalization and relative quantification, yielding superiorly comparable results from pixel to pixel and tissue to tissue [6, 22, 23]. This work only selected the latest developments of novel matrices and on-tissue chemical derivatization reagents for MALDI-MSI.

\section{Novel matrices for MALDI-MSI}

Ideal matrices for MALDI-MSI need several additional features in comparison with matrices for MALDI-MS used in non-imaging fields. There are some fundamental properties for substances that can be used as MALDI matrix for all applications: (i) MALDI matrices display strong and efficient absorption in the region of commonly used UV or IR laser wavelengths; (ii) minimal matrix background signals and adducts with target analytes ("chemical noise") should result from matrices, especially in the low mass range (typically $m / z<500$ ), thus enabling visualization of the spatial distribution of small molecules; (iii) the ability to interact with analytes is required for matrices to form co-crystals; (iv) matrices must be able to effectively ionize the analytes, resulting in protonated ions in positive ion mode or deprotonated ions in negative ion mode. In addition to these general requirements for MALDI matrices, a matrix suitable for tissue imaging applications should fulfill the criteria: (A) It should have high vacuum stability in the mass spectrometer for at least several hours in a typical imaging situation or for even longer acquisition times in serial imaging of multiple tissue sections, for example, entire clinical cohorts, with high spatial resolution. (B) The application of matrices onto tissue should be practical in a routine laboratory, i.e., reproducible and not time-consuming. Sublimation and automatic spray-coating methods are often used due to easy handling and sufficient reproducibility. (C) The generation of uniform, small cocrystals is necessary for images with reproducibility and high spatial resolution, which is also limited by minimal laser spot size and the desired sensitivity (since the ablated area, which decreases with the square of the step size, strongly correlates with sensitivity). Thus, high spatial resolution requires an optimized matrix, which can promote efficient ionization of target analytes. (D) For the untargeted discovery of biomarkers, matrices suitable for both positive and negative ion modes (also called dual-polarity) cannot only save precious tissue but also provide broader molecular coverage. The ability of ionizing more types of analytes in single ion mode (positive or negative) would be beneficial for detecting more molecular species simultaneously. (E) Owing to physiologic salts naturally present in tissue, salt tolerance allows the direct application of matrices without additional wash protocols. Finally, chemical stability, cost, toxicity, and promotion of analyte fragmentation need to be considered. In the field of MALDIMSI, performance with desired detection sensitivity, spatial resolution, and molecular coverage is in large part dependent on matrix choices and matrix application. Because MALDIMSI is becoming more and more popular in different disciplines and the existing matrices do not always meet all 
expectations stated above, many laboratories are developing novel matrices with at least some of the abovementioned requirements.

Currently, most very oft-used MALDI-MSI matrices like 2,5-DHB and CHCA were developed for specific analytes during empiric research. Different substance classes, such as small organic molecules, graphene, graphene oxide, nanoparticles, metal oxides, ionic liquids, and conjugated polymers, are presently developed, tested for their suitability as MALDIMSI matrices, and reviewed by various papers $[4,11,20]$. Small organic molecules are the most widespread matrices used in MALDI-MSI. Since recent reviews $[11,20]$ have already described some novel organic matrices applied for MALDI-MSI including 1,5-diaminonapthalene [24], 4phenyl-a-cyanocinnamic acid amide [25], alkylated 2,5DHB [26], 1,8-di(piperidinyl)-naphthalene [27], and 4,5-(bis(dimethylamino)naphthalen-1-yl)furan-2,5-dione (4maleicanhydrido proton sponge, MAPS) [28], this work selected only the latest efforts about novel organic matrices for MALDI-MSI from 2017. This section contains the rationally designed and synthesized as well as commercially available small organic molecules whose properties as bona fide MALDI matrices for the detection and imaging of analytes in tissue sections have recently been discovered or characterized (Fig. 2 and Table 1).

\section{Rationally designed and synthesized novel matrices}

(E)-4-(2,5-Dihydroxyphenyl)but-3-en-2-one (2,5-cDHA) was designed and synthesized by Yang and coworkers [29] among<smiles>CC(=O)/C=C/c1cc(O)ccc1O</smiles>

2,5-CDHA<smiles>COc1ccc(/C=C/C(=O)O)cc1OC</smiles>

DMCA<smiles>CNc1ccccc1C(=O)O</smiles>

$\mathrm{COOH}-\mathrm{NHMe}$<smiles>Nc1cccc2c(=O)[nH][nH]c(=O)c12</smiles>

3-APH

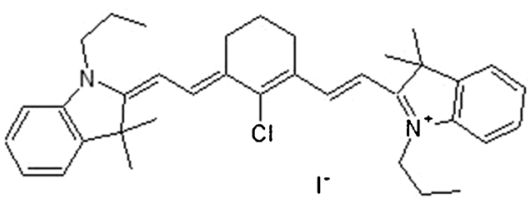

IR-780<smiles>C(/C=C/c1ccccc1)=C\c1ccccc1</smiles>

DPH other derivatives, using Wittig reaction of $2^{\prime}, 5^{\prime}$ dihydroxybenzaldehyde with (acetylmethylene)triphenylphosphorane. 2,5-cDHA was applied to tissue by a two-step spraying approach, producing small crystals (1$2 \mu \mathrm{m}$ ). Unlike the parent matrix 2,5-DHA, the 2,5-cDHA proved to be vacuum-stable for more than $24 \mathrm{~h}$ in the Bruker Rapiflex mass spectrometer, whose source has a high vacuum $\left(4.4 * 10^{-7} \mathrm{mbar}\right.$ ) and heated (around $35^{\circ} \mathrm{C}$ ) environment. As a result, 2,5-cDHA was used for the visualization of proteins in mouse brain at high spatial resolution $(<10 \mu \mathrm{m})$ and for many hours without concern of matrix loss in the mass spectrometer. Additionally, 2,5-cDHA was also used for imaging of lipids in both positive and negative ion modes.

Huang and coworkers [30] rationally designed and synthesized a series of novel matrix candidates, including 2-(methylamino)benzoic acid (COOH-NHMe), candidate as a MALDI matrix for imaging. The matrix $\mathrm{COOH}-\mathrm{NHMe}$ was synthesized by adding a methyl group to anthranilic acid using $\mathrm{CH}_{3} \mathrm{I}$ in basic conditions. The new methylated anthranilic acid derivative features both basic and acidic functional groups and thus showed the ability to be used in both positive and negative ion modes for the ionization and detection of lipids and proteins in mouse brain tissue. In comparison with commercially available matrices, $\mathrm{COOH}-\mathrm{NHMe}$ was able to visualize more lipid and protein species.

\section{Newly discovered novel matrices}

N-Phenyl-2-naphthylamine (PNA) is usually used as an antioxidant for natural and synthetic rubber. Liu and coworkers<smiles>c1ccc(Nc2ccc3ccccc3c2)cc1</smiles>

PNA<smiles>N#Cc1c(O)ccc(O)c1C#N</smiles>

$\mathrm{DCH}$<smiles>NCCNc1cccc2ccccc12</smiles>

NEDC<smiles>CC(=CC(C#N)C#N)c1ccc(C(C)(C)C)cc1</smiles>

Fig. 2 Structures of selected novel MALDI matrices for imaging 


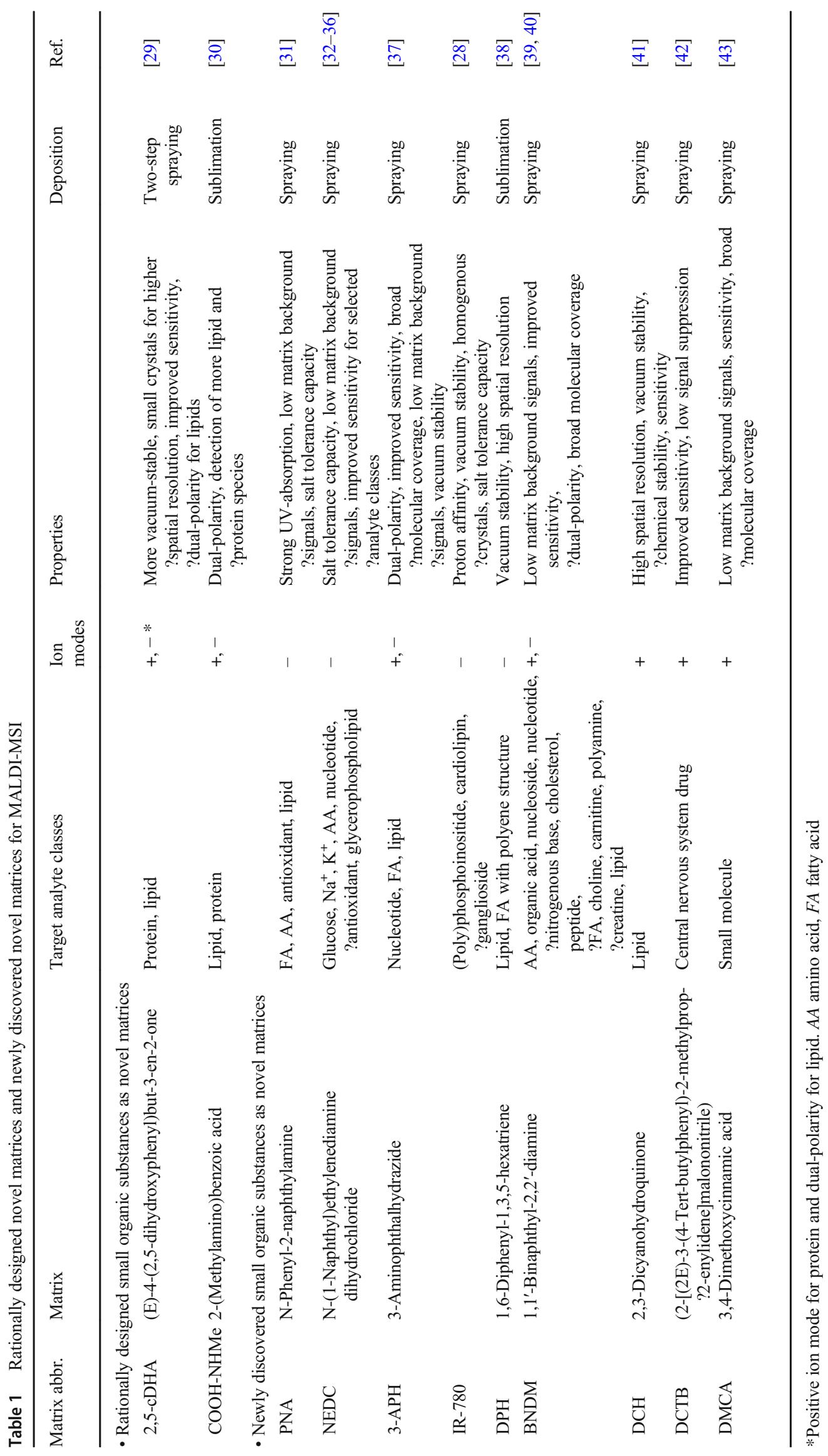


[31] developed PNA as a matrix for imaging of smallmolecule metabolites, including free fatty acids, amino acids, antioxidants, and phospholipids. On account of its strong UV absorption, low background interference in the $\mathrm{m} / \mathrm{z}$, range of $<$ 500 and considerable salt tolerance, the unique distributions and changes of 89 small-molecule metabolites were visualized in negative ion mode in brain tissue of a middle cerebral artery occlusion (MCAO) rat model of ischemic stroke.

$\mathrm{N}$-(1-Naphthyl)ethylenediamine dihydrochloride (NEDC) has been known as a commercially available coupling agent for spectrophotometric analysis. Since Chen and coworkers [33] discovered NEDC as a high-salt tolerance matrix for the analysis of glucose as [glucose $\left.+\mathrm{Cl}^{-}\right]^{-}$in rat brain microdialysates in negative ion mode, several contributions of NEDC could be found in the MS imaging field. Hou and coworkers [34] applied NEDC to mouse brain sections for visualization of sodium and potassium distribution. Here, sodium and potassium were detected as chloride ion adducts. Wang and coworkers [36] were able to visualize distributions of glycerophospholipids and small-molecule metabolites below $\mathrm{m} / \mathrm{z} 400$, including glucose in various mouse organs. Li and coworkers [35] successfully used NEDC for imaging of the change of lipid metabolism and the levels of amino acids, nucleotides, and antioxidants in brain tissue of an orthotopic glioma xenograft model. Barré and coworkers [36] compared NEDC with 9-AA for imaging of small metabolites in diffuse large B cell lymphoma xenograft mouse model. With a higher signal-to-noise ratio for metabolites and less matrix background, NEDC appears to be a better matrix for adenosine monophosphate (AMP), adenosine diphosphate (ADP), and adenosine triphosphate (ATP) than 9-AA.

3-Aminophthalhydrazide (3-APH, also known as luminol) is a commercially available and very effective chemiluminescent substrate. 3-APH was evaluated by Li and coworkers [37] as a dual-polarity matrix with superior performance than common matrices such as 2,5-DHB, CHCA, and 9-AA. 3-APH was able to detect and give a spatial distribution of 159 and 207 metabolites in the mouse brain in the positive and negative ion modes, respectively. Among the detected metabolites were nucleotides, fatty acids, glycerolipids, glycerophospholipids, sphingolipids, and saccharolipids. Thus, 3-APH was demonstrated to have some improved features including high sensitivity, broad molecular coverage, low background noise, and high vacuum stability.

IR-780 is a commercially available near-infrared fluorescent dye. Li and coworkers [28] successfully screened and optimized the application of IR-780 as a matrix for visualization of various high-molecule lipids, including (poly-)phosphoinositides, cardiolipins, and gangliosides in acute traumatic brain injury tissues in negative ion mode. IR-780 was proved to possess various good properties including strong UV absorption, high proton affinity, good salt tolerance ability, homogeneous co-crystallization, and high vacuum stability. Thus, it was suggested as an almost ideal matrix for imaging.

1,6-Diphenyl-1,3,5-hexatriene (DPH) is a commercially available fluorescent dye for the detection and localization of lipids in fluorescence imaging. Ibrahim and coworkers [38] presented DPH as a suitable and effective matrix for imaging of lipids and fatty acids in rat and mouse brain tissues in negative ion mode. It was proposed that the interaction with the acyl chain of lipids and fatty acids is accountable for the features of DPH as a matrix for lipids and fatty acids with hydrophobic polyene structure. The possibility of application via sublimation and the stability for at least $24 \mathrm{~h}$ under high vacuum (10-7 Torr) allowed DPH for the application for high spatial resolution imaging. Use of relative low laser energy avoided the fragmentation of lipids.

The enantiomers and derivatives of commercial available $1,1^{\prime}$-Binaphthyl-2,2'-diamine (BNDM) are widely used in asymmetric syntheses. Sun and coworkers [40] developed BNDM as a dual-polarity matrix with low background interference and high sensitivity. BNDM could be applied for imaging of 301 negative metabolite ions and 175 positive metabolite ions, including amino acids, organic acids, nucleosides, nucleotides, nitrogenous bases, cholesterols, peptides, fatty acids, cholines, carnitines, polyamines, creatine, and phospholipids in rat brain. Additionally, BNDM could give the spatial information of various metabolites in different mouse lung cancer tissue sections. In another work, Sun and coworkers [39] optimized BNDM for the imaging application of amino acids, phenolic acids, fatty acids, oligosaccharides, cholines, polyamines, tanshinones, and phospholipids in Salvia miltiorrhiza Bge.

2,3-Dicyanohydroquinone ( $\mathrm{DCH})$ is originally known as a fluorescent dye and was applied by Liu and coworkers [41] as a new matrix for imaging of lipids in biological tissues. In contrast to commonly used matrices, more lipids could be detected from mouse brain and germinating Chinese yew seed tissue sections in positive ion mode. Strong UV absorption, high vacuum stability, profound chemical stability, and formation of homogenous small crystals make for a good matrix with the superior performance, including high spatial resolution and reproducibility.

In 2000, Ulmer and coworkers [44] proved DCTB (2-[(2E)-3-(4-tert-butylphenyl)-2-methylprop-2enylidene]malononitrile) as an electron transfer matrix for the analysis of labile compounds. Recently, Rzagalinski and coworkers [42] found the theoretical and experimental evidence that DCTB is a proton transfer matrix. DCTB was applied for imaging of central nervous system drugs in mouse brain tissue on positive ion mode. Despite the solubility and vacuum stability drawbacks, DCTB was applied for quantitative imaging of the adrenergic receptor agonist xylazine in mouse brain tissue with significant improvements of signal intensity over CHCA. 
He and coworkers [43] investigated 3,4-dimethoxycinnamic acid (DMCA) as a promising matrix for imaging of endogenous low molecular weight metabolites $(\mathrm{m} / z<500 \mathrm{Da})$ on rat liver, rat brain, and germinating Chinese yew seed tissue, with 303 , 200, and 248 metabolites, respectively. Using DMCA, more low molecular weight metabolites $(\mathrm{m} / \mathrm{z}<500)$ could be detected and imaged than using other commonly used matrices such as 2,5-DHB, CHCA, 2-mercaptobenzothiazole (2-MBT), graphene oxide, and silver nanoparticles. Due to the broad molecular coverage and low background signals, DMCA was established as a powerful matrix with high ionization efficiency for small molecules.

\section{On-tissue chemical derivatization reagents}

Nowadays, MALDI-MSI draws more and more attention as a label-free imaging technique that can visualize various metabolites in a single measurement. However, the MALDI-MSI technique faces some challenges such as detection sensitivity for small molecule analytes, extend of metabolic coverage, more comprehensive identification of isomers, and so on.

The detection of some metabolites in tissue sections by MALDI-MSI is sometimes hindered by their ionization efficiencies, and additionally, also by background interferences from MALDI matrix or tissue components, sampling size, ion suppression effects, and in-source fragmentation. Besides, the broad dynamic range of on-tissue metabolite concentrations and their diverse functional groups are responsible for distinct ionization efficiencies. To solve the detection problem of small metabolites in tissue sections, development of more effective matrices for MALDI with negligible matrix background and optimization of matrix deposition methods are just two strategies to improve their detection sensitivities. However, more strategies are required. On-tissue chemical derivatization (OTCD) is an alternative approach to improve ionization efficiency of targeted analytes in MALDI-MSI for the in situ detection of analytes. OTCD of small molecule analytes can increase their molecular mass, resulting in mass shifting the derivatization product ions out of the "chemical noise" range. Optimally, the derivatization products can be ionized more efficiently than analytes without derivatization, resulting in improved detection sensitivity in MALDI-MSI for the in situ detection. Finally, broader molecular coverage can be achieved. Furthermore, the specificity in MALDI-MSI can be improved by OTCD that allows specific chemical reactions for the identification of functional groups and their positions in target analytes. At best, OTCD reagents can serve as a reactive matrix, which cannot only selectively react with analytes in tissue sections but also assist in desorption and ionization in MALDI-MS.

Chemical derivatization in solution is a well-developed strategy for the detection of analytes in capillary electrophoresis [45, 46], gas chromatography [47], and highperformance liquid chromatography $[45,47]$ coupled with optical absorption spectrometry or electrospray ionization mass spectrometry (ESI) [48-51] for the following purposes: enabling of detection, improved structure elucidation in terms of structural isomers, simplified identification of functional groups, quantification, and improved molecular coverage.

In-solution chemical derivatization methods have found various applications in MALDI-MS [52]. To date, more and more chemical derivatization approaches are developed for on-tissue applications followed by MALDI-MSI measurements. In comparison to in-solution chemical derivatization, OTCD needs to overcome a couple of challenges including relatively low derivatization efficiency, interferences due to excess derivatization reagent, and delocalization due to the additional spray-coating step and incubation in the humid atmosphere. Thus, complex chemical reaction conditions often used in solution cannot easily be adapted and reconstructed for on-tissue chemical reactions. Optimally, OTCD can be performed at room temperature without the requirement of additional specific buffers and with short reaction times. Generally, OTCD employs an automatic sprayer to apply derivatization reagents directly onto tissue sections before incubation in a humid chamber at room temperature or slightly increased temperature for several hours. Several review papers $[5,53,54]$ have already included the work from Holster and coworkers [55], who developed a linkage-specific two-step OTCD process for obtaining spatial distribution information of linkage-specific N-glycan isomers from FFPE tissue sections by using the MALDI-MSI technique. And although several other review papers $[20,56-58]$ have described new developments of mass spectrometric imaging, which described among other methods also several MALDI-MSI approaches using OTCD, we present a comprehensive overview about recent developments in OTCD of functional groups including amine, phenolic hydroxyl, carbonyl, carboxylic acid, thiol, and double bond, for applications in the MALDI-MS imaging field (Table 2 and Figs. 3, 4, 5, 6, 7, and 8).

\section{Target functional group: Amine}

With trans-cinnamaldehyde/4-hydroxy-3methoxycinnamaldehyde The functional aldehyde group reacts easily with primary amines, forming a stable Schiff's base. Using this reaction, Manier and coworkers [59] investigated trans-cinnamaldehyde for the derivatization of isoniazid, an anti-tuberculosis drug, in rabbit lung tissue sections. Later, Manier and coworkers [60] applied 4-hydroxy-3methoxycinnamaldehyde (CA) for the visualization of dopamine, norepinephrine, and epinephrine in porcine adrenal gland tissue sections and $\gamma$-aminobutyric acid in rat brain tissue sections. The pre-coating method of the CA resulted in enhanced sensitivity with minimal analyte delocalization. 
Table 2 MALDI-MSI approaches with on-tissue chemical derivatization of analytes in tissue sections

\begin{tabular}{llll}
\hline Target analytes in tissue sections & OTCD reagent & Solution & $\begin{array}{l}\text { Application and } \\
\text { incubation }\end{array}$
\end{tabular}

Amine as targeted functional groups

Isoniazid

Dopamine, norepinephrine, epinephrine, $\gamma$-aminobutyric acid

Glycine, alanine, serine, proline, CA

valine, threonine,

isoleucine/leucine, aspartate, glutamine, lysine, glutamate, tryptophan, dopamine,

$\gamma$-aminobutyric acid, taurine,

3-methoxytyramine,

serotonin,

L-dihydroxyphenylalanine

Glycine, alanine, aminobutenoic CA

acid, serine, $\gamma$-aminobutyric

acid and more other metabo-

lites

67 small-molecule metabolites

including amino acids,

neurotransmitters, dipeptides

and others

Neuropeptides

$\mathrm{NBA}+\mathrm{hv}$

Amino acids excluding lysine, serine, histidine, threonine,

aspartate and arginine

Glycine, alanine, serine, proline, TAHS

valine, threonine,

isoleucine/leucine, aspartate,

glutamine, lysine, glutamate,

tryptophan, dopamine,

$\gamma$-aminobutyric acid, taurine,

3-methoxytyramine,

serotonin,

L-dihydroxyphenylalanine

Phenylalanine, tyrosine

TAHS

Noradrenaline

TAHS

Glutamine

TAHS

Dopamine, tyrosine, tryptamine, DPP-TFB**, tyramine, phenethylamine, 3-methoxytyramine, serotonin, $\gamma$-aminobutyric acid, glutamate

Dopamine and amphetamine, $\beta$-N-methylamino-L-alanine

\section{TMP-TFB}

DPP*, TMP,
PBDPP*

DPP-TFB
$50 \%$ in $\mathrm{MeOH}$

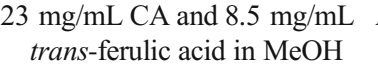

$4 \mathrm{mg} / \mathrm{mL}$ in $50 \% \mathrm{MeOH}$

Automatic

spraying, overnight at

RT
[59]

Adrenal gland tissue sections of pig, brain tissue sections of rat

Brain tissue sections from female C57BL/6J mice
$20 \mathrm{mg} / \mathrm{mL}$ in $\mathrm{MeOH}$

$5 \mathrm{mg} / \mathrm{mL}$ in $50 \% \mathrm{MeOH}$

$5 \mathrm{mg} / \mathrm{mL}$ in

$\mathrm{ACN} / \mathrm{EtOH} / \mathrm{FA} / \mathrm{H}_{2} \mathrm{O}$

$5 \mathrm{mg} / \mathrm{mL}$ in $\mathrm{ACN}$

$5 \mathrm{mg} / \mathrm{mL}$ in $50 \%$ ACN

$5 \mathrm{mg} / \mathrm{mL}$ in $\mathrm{ACN}$

$5 \mathrm{mg} / \mathrm{mL}$ in $\mathrm{ACN}$

$5 \mathrm{mg} / \mathrm{mL}$ in $\mathrm{ACN}$

$0.09 \mathrm{mg} / \mathrm{mL}$ in $50 \% \mathrm{MeOH}$ with $0.06 \%$ TEA

$1.11 \mathrm{mg} / \mathrm{mL}$ in $75 \% \mathrm{MeOH}$ with $0.05 \%$ TEA, $1 \mathrm{mg} / \mathrm{mL}$ in $83 \% \mathrm{MeOH}$ with $0.05 \%$ TEA, $0.2 \mathrm{mg} / \mathrm{mL}$ in $80 \%$ $\mathrm{MeOH}$ with $0.07 \%$ TEA

$5 \mathrm{mg} / \mathrm{mL}$ in $\mathrm{MeOH}$
Electrospraying Leaf and root tissue sections of two different maize genotypes (B73 and Mo17)

Electrospraying, Brain tissue sections of rats overnight at $37{ }^{\circ} \mathrm{C}$

$\begin{array}{cc}\text { Automatic } & \text { Brain tissue sections from mouse } \\ \text { spraying, } & \text { brain }\end{array}$ nanosecond with $h v$

Airbrush, overnight at $55{ }^{\circ} \mathrm{C}$

Automatic spraying, overnight at RT

Liver tissue sections from xenograft mouse models of human colon cancer

Brain tissue sections from female C57BL/6 J mice
Automatic Liver tissue sections from a H460 [66] spraying, $24 \mathrm{~h}$ human NSCLC xenograft at $55^{\circ} \mathrm{C} \quad$ mouse model
Airbrush, Adrenal gland tissue sections from $15 \mathrm{~min}$ at $55^{\circ} \mathrm{C}$ tumor patients
Automatic
Tumor and benign tissue sections spraying, $24 \mathrm{~h}$ from tumor patients at $55^{\circ} \mathrm{C}$
Automatic spraying,
Brain tissue sections from treated [69] $30 \mathrm{~min}$ at RT and control male Sprague-Dawley rats and C57BL/6J male mice, brain tis- sue sections from primate
Automatic spraying, Brain tissue sections from the treated and untreated C57BL/6J 15 min at RT male mice, male Wistar rat pups or adult Sprague-Dawley rats


Table 2 (continued)

\section{Target analytes in tissue sections \\ Glycine, alanine, serine, proline, \\ valine, threonine, \\ isoleucine/leucine, aspartate, \\ glutamine, lysine, glutamate, \\ tryptophan, dopamine, \\ $\gamma$-aminobutyric acid, taurine, \\ 3-methoxytyramine, \\ serotonin, \\ L-dihydroxyphenylalanine \\ Glutamate, $\gamma$-aminobutyric acid}

Solution
Application and Tissue

incubation
DPP-TFB

DPP-TFB

Dopamine, serotonin,

norepinephrine

Dopamine, 3-methoxytyramine

DPP-TFB

DPP-TFB

Dopamine, glycine, alanine,

$\gamma$-aminobutyric acid, proline,

valine, threonine, taurine,

leucine, aspartate, tyramine,

glutamine, lysine, glutamate,

tryptamine, 3-

-methoxytyramine, tyrosine,

L-dihydroxyphenylalanine

Dopamine, serotonin,

$\gamma$-aminobutyric acid,

histamine, threonine,

phenethylamine,

methylhistamine, agmatine,

adenine, tyramine, lysine,

tryptamine,

L-dihydroxyphenylalanine

Dopaminergic and serotonergic neurotransmitters and their

associated metabolites

containing primary and

secondary amine groups

Dopamine, $\gamma$-aminobutyric acid

DPP-TFB

$\begin{aligned} & \text { Automatic } \\ & \text { spraying, } \\ & \text { overnight at } \\ & \text { RT }\end{aligned}$
C57BL $/ 6 \mathrm{~J}$ mice

$1.33 \mathrm{mg} / \mathrm{mL}$ in $\mathrm{MeOH}$

$1.3 \mathrm{mg} / \mathrm{mL}$ in $\mathrm{MeOH}$

$1.3 \mathrm{mg} / \mathrm{mL}$ in $\mathrm{MeOH}$

$5 \mathrm{mg} / \mathrm{mL}$ in $\mathrm{MeOH}$

\author{
$1.33 \mathrm{mg} / \mathrm{mL}$ in $75 \% \mathrm{MeOH}$ \\ with $0.05 \%$ TEA
}

FMP-8*, FMP-9*, $4.4 \mathrm{mM}$ in $70 \% \mathrm{ACN}$ FMP-10*

FMP-10* $\quad 1.8 \mathrm{mg} / \mathrm{mL}$ in $70 \% \mathrm{ACN}$

Phenolic hydroxyl as targeted functional groups

\begin{tabular}{|c|c|c|}
\hline $\begin{array}{l}\text { Cannabinoids and their } \\
\text { metabolites }\end{array}$ & FMPTS & $10 \mathrm{mg} / \mathrm{mL}$ in $\mathrm{ACN}$ \\
\hline $\begin{array}{l}\text { Catecholamines (dopamine, } \\
\text { epinephrine, norepinephrine) }\end{array}$ & $(\mathrm{N}-\mathrm{Me}) \mathrm{Py}^{+} \mathrm{B}(\mathrm{OH})_{2}{ }^{*}$ & $12 \mathrm{mg} / \mathrm{mL}$ in $60 \% \mathrm{ACN}$ \\
\hline $\begin{array}{l}\text { Dopaminergic and serotonergic } \\
\text { neurotransmitters and their } \\
\text { associated metabolites } \\
\text { containing phenolic hydroxyl } \\
\text { groups } \\
\text { arbonyl as targeted functional gy }\end{array}$ & $\begin{array}{l}\text { FMP-8*, FMP-9*, } \\
\text { FMP-10* }\end{array}$ & $4.4 \mathrm{mM}$ in $70 \% \mathrm{ACN}$ \\
\hline Fluticasone propionate & DMNTH* $^{*}, \mathrm{DNPH}^{*}$ & $\begin{array}{l}5 \mathrm{mg} / \mathrm{mL} \text { in } 50 \% \mathrm{ACN} \text { with } \\
0.1 \% \mathrm{TFA}, 4 \mathrm{mg} / \mathrm{mL} \text { in } \\
50 \% \mathrm{ACN}\end{array}$ \\
\hline $\begin{array}{l}\text { 11-Dehydrocorticosterone and } \\
\text { corticosterone }\end{array}$ & GirT & \\
\hline
\end{tabular}

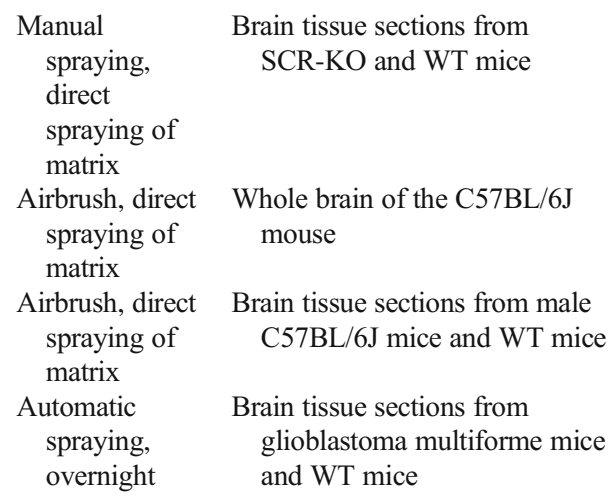
Automatic Brain tissue sections from rock spraying, $24 \mathrm{~h} \quad$ crabs Cancer irroratus at RT

\section{Automatic spraying, no incubation}
Automatic spraying, no incubation

Airbrush
Automatic
spraying
Automatic
spraying, no
incubation

Spotting, $48 \mathrm{~h}$ at Rat lung tissue sections $37^{\circ} \mathrm{C}$

Human hair pig
Brain tissue sections from treated and untreated rat and primate models of Parkinsonism, brain tissue sections from a patient with Parkinson's disease

Brain tissue sections from GPR37 $\mathrm{KO}$ mice and WT mice

Adrenal gland tissue sections from

Brain tissue sections from treated and untreated rats and primate models of Parkinsonism, brain tissue sections from a patient with Parkinson's disease

Adrenal gland tissue sections of Sprague-Dawley rat and brain

(1)


Table 2 (continued)

\begin{tabular}{|c|c|c|c|c|c|}
\hline Target analytes in tissue sections & OTCD reagent & Solution & $\begin{array}{l}\text { Application and } \\
\text { incubation }\end{array}$ & Tissue & Ref. \\
\hline & & $\begin{array}{l}0.15 \mathrm{mg} / \mathrm{cm}^{2}, \text { addition } \\
\text { spraying of } \mathrm{MeOH} \text { with } \\
0.2 \% \mathrm{TFA}\end{array}$ & $\begin{array}{l}\text { Precoated, } \\
60 \mathrm{~min}^{\circ} \text { at } \\
40^{\circ} \mathrm{C}\end{array}$ & $\begin{array}{l}\text { tissue sections of } \mathrm{C} 57 \mathrm{BL} / 6 \\
\text { mice }\end{array}$ & \\
\hline Triamcinolone acetonide & GirT & $\begin{array}{l}5 \mathrm{mg} / \mathrm{mL} \text { in } \mathrm{MeOH} \text { with } 0.2 \% \\
\text { TFA }\end{array}$ & $\begin{array}{l}\text { Automatic } \\
\text { spraying, } \\
150 \text { min at } \\
40{ }^{\circ} \mathrm{C}\end{array}$ & Human incubated cartilage & [82] \\
\hline Testosterone & GirT & $5 \mathrm{mg} / \mathrm{mL}$ in $2.5 \%$ acetic acid & $\begin{array}{l}\text { Airbrush, } \\
\quad 90 \text { min at RT }\end{array}$ & $\begin{array}{l}\text { Testis tissue sections of C57BL/6 } \\
\text { mice after human chorionic go- } \\
\text { nadotrophin treatment }\end{array}$ & [83] \\
\hline $\begin{array}{l}\text { Testosterone and } \\
5 \alpha \text {-dihydrotestosterone }\end{array}$ & GirT & $\begin{array}{l}5 \mathrm{mg} / \mathrm{mL} \text { in } 80 \% \mathrm{MeOH} \text { with } \\
0.1 \% \text { TFA }\end{array}$ & $\begin{array}{l}\text { Automatic } \\
\text { spraying, } \\
60 \text { min at } \\
40{ }^{\circ} \mathrm{C}\end{array}$ & $\begin{array}{l}\text { Testis tissue sections of C57BL/6 } \\
\text { mice and prostate tissue sec- } \\
\text { tions of Sprague-Dawley rats } \\
\text { after human chorionic gonado- } \\
\text { trophin treatment }\end{array}$ & [84] \\
\hline $\begin{array}{l}\text { Cortisone, aldosterone, } \\
\text { 18-oxocortisol and progester- } \\
\text { one }\end{array}$ & GirT & $10 \mathrm{mg} / \mathrm{mL}$ in $20 \%$ acetic acid & $\begin{array}{l}\text { Airbrush, } \\
\quad 90 \text { min at RT }\end{array}$ & $\begin{array}{l}\text { Adrenal gland tissue sections of } \\
\text { human patients and Sprague } \\
\text { Dawley rats }\end{array}$ & [85] \\
\hline $\begin{array}{l}\text { Abscisic acid and } \\
\text { 12-oxo-phytodienoic acid }\end{array}$ & GirT & $\begin{array}{l}5 \mathrm{mg} / \mathrm{mL} \text { in } 80 \% \mathrm{MeOH} \text { with } \\
2 \% \mathrm{TFA}\end{array}$ & $\begin{array}{l}\text { Airbrush, } \\
\quad 30 \text { min at RT }\end{array}$ & $\begin{array}{l}\text { Immature } P . \text { vulgaris } L . \text { seed } \\
\text { sections }\end{array}$ & [86] \\
\hline $\begin{array}{l}\text { Pyruvic acid, glycolaldehyde, } \\
\text { 2-pentenal, dithylacetone, } \\
\text { 1-hexanal, 1-heptanal, } \\
\text { jasmonic acid, dotriacontanal } \\
\text { and more other metabolites }\end{array}$ & GirT & $\begin{array}{l}10 \mathrm{mg} / \mathrm{mL} \text { in } \mathrm{MeOH} \text { with } 2 \% \\
\text { TFA }\end{array}$ & Electrospraying & $\begin{array}{l}\text { Leaf and root tissue sections of } \\
\text { two different maize genotypes } \\
\text { (B73 and Mo17) }\end{array}$ & [62] \\
\hline $\begin{array}{l}\text { 11-Dehydrocorticosterone, } \\
\text { corticosterone }\end{array}$ & GirT & $\begin{array}{l}5 \mathrm{mg} / \mathrm{mL} \text { in } 80 \% \mathrm{MeOH} \text { with } \\
0.2 \% \text { TFA }\end{array}$ & $\begin{array}{l}\text { Electrospraying, } \\
1 \mathrm{~h} \text { at } 40^{\circ} \mathrm{C}\end{array}$ & $\begin{array}{l}\text { Brain tissue sections of } \\
\text { Sprague-Dawley rats }\end{array}$ & [63] \\
\hline $\begin{array}{l}\text { Aldosterone, cortisol, cortisone, } \\
\text { 18-OH-corticosterone }\end{array}$ & GirT & $10 \mathrm{mg} / \mathrm{mL}$ in $20 \%$ acetic acid & $\begin{array}{l}\text { Airbrush, } \\
\quad 60 \text { min at RT }\end{array}$ & $\begin{array}{l}\text { Tissue sections of human adrenal } \\
\text { glands }\end{array}$ & [67] \\
\hline \multicolumn{6}{|c|}{ Carboxylic acid as targeted functional groups } \\
\hline $\begin{array}{l}\text { Docosahexaenoic acid, } \\
\text { arachidonic acid oleic acid }\end{array}$ & PA & $2 \mathrm{mM}$ with $10 \mathrm{mM}$ of & $\begin{array}{l}\text { Electrospraying } \\
\text { or airbrush }\end{array}$ & Brain tissue sections from rats & [87] \\
\hline
\end{tabular}

activation reagents in $\mathrm{ACN}$ or airbrush

eicosapentaenoic acid, linoleic acid

3-Maleylpyruvate,

$\mathrm{N}$-acetyl-L-glutamate,

palmitic acid, oleic acid,

stearic acid and more other metabolites

Fatty acids (C16:1, C16:0, C18:2, C18:1, C18:0, C18:3,

C20:4, C20:0, C22:6, C22:4)

PA

$6 \mathrm{mM}$ PA and $30 \mathrm{mM}$

activation reagents in $\mathrm{ACN}$

Electrospraying

Leaf and root tissue sections of two different maize genotypes (B73 and Mo17)

\section{DMPI}

insulin, glutathione, cysteine, cysteinylglycine

Double bond groups

PC 36:1, PS 36:2 isomers

PC 34:1, PC 36:1 isomers

$\mathrm{BPh}^{*}$

PC 34:1, PC 36:1 isomers

Ozone

\author{
Benzaldehyde \\ CHC-MAL $* * *$
}

Vapor of benzaldehyde
$3 \mathrm{mM}$ with $1 \mathrm{mM}$ HATU in $80 \%$ ACN

$10 \mathrm{mg} / \mathrm{mL}$ in $50 \% \mathrm{ACN}$

Automatic
spraying

Electrospraying

Tumor and normal tissue sections of patients with thyroid of rat

Liver and pancreas tissue sections [89]

$20 \mathrm{mg} / \mathrm{mL}$ in solution (ACN: $3 \mathrm{~min}$ with isopropanol: $\mathrm{H}_{2} \mathrm{O}, 6: 3: 1 \quad$ UV-light with $0.5 \%$ TFA)

Gas of pig, tumor tissue sections of mouse xenograft
Custom-made Brain tissue sections of reaction $\quad$ C57BL6/ $\mathrm{N}$ mice chamber, triggered by $254 \mathrm{~nm}$
C57BL6/N mice and tegument of $S$. mansoni
High-pressure Brain tissue sections of linear ion trap ND2:SmoA1 transgenic mice with ozone containing tumors carcinoma, brain tissue sections 
Table 2 (continued)

\begin{tabular}{|c|c|c|c|c|}
\hline Target analytes in tissue sections & OTCD reagent & Solution & $\begin{array}{l}\text { Application and } \\
\text { incubation }\end{array}$ & Tissue \\
\hline PC 34:1 isomers & Ozone & Ozone from an ozone generator & $\begin{array}{l}\text { Glass flask } \\
\text { flushed with } \\
\text { the flow of } \\
\text { ozone, up to } \\
30 \text { min }\end{array}$ & $\begin{array}{l}\text { Brain tissue sections of BALB } / \mathrm{c} \\
\text { mice, human colon tissue sec- } \\
\text { tions }\end{array}$ \\
\hline
\end{tabular}

$C A$, 4-hydroxy-3-methoxycinnamaldehyde; $N B A$, 2-nitrobenzaldehyde; $T A H S, \mathrm{p}-N, N, N$-trimethylammonioanilyl $N$-hydroxysuccinimidyl carbamate iodide; $D P P-T F B$, 2,4-diphenyl-pyranylium tetrafluoroborate; $D P P, 2,4$-diphenyl-pyranylium; $P B D P P, 1,4$-phenylene-4,4'-bis (2,6-diphenyl-4pyrylium); $T M P, 2,4,6$-trimethylpyrylium; FMP-8: 4-(10-bromoanthracen-9-yl)-2-fluoro-1-methylpyridin-1-ium iodide; $F M P$-9, 4-(anthracen-9-yl)-2fluoro-1-ethylpyridin-1-ium iodide; FMP-10, 4-(anthracen-9-yl)-2-fluoro-1-methylpyridin-1-ium iodide; FMPTS, 2-fluoro-1-methylpyridinium $p$ toluenesulfonate; $(\mathrm{N}-\mathrm{Me}) \mathrm{Py}+\mathrm{B}(\mathrm{OH})_{2}$, 4-(N-methyl)pyridinium boronic acid; $\mathrm{DNPH}$, 2,4-dinitrophenylhydrazine; $D M N T H$, 4-dimethylamino-6-(4methoxy-1-naphthyl)-1,3,5-triazine-2-hydrazine; GirT, Girard's reagent T; PA, 2-picolylamine (PA); DMPI, N,N-dimethylpiperazine iodide; $C H C$ Mal, (E)-2-cyano-N-(2-(2,5-dioxo-2,5-dihydro-1H-pyrrol-1-yl)ethyl)-3-(4-hydroxyphenyl)-acrylamide (CHC-Mal); $B P h$, benzophenone; $A C N$, acetonitrile; TFA, trifluoroacetic acid; $E t O H$, ethanol; FA, formic acid; TEA, triethylamine; $R T$, room temperature; HATU, 2-(7-azabenzotriazol-1-yl)$\mathrm{N}, \mathrm{N}, \mathrm{N}^{\prime}, \mathrm{N}^{\prime}$-tetramethyluronium hexafluorophosphate; $\mathrm{MeOH}$, methanol

*Reactive matrix; **Reactive matrix in high concentration; $* * *$ Reactive matrix for small thiol-containing molecules

CA was also used by Esteve and coworkers [61] for the comparison with THAS and DPP-TFB. Dueñas and coworkers [62] also applied CA for a proof of concept experiment, in which various classes of compounds containing a primary amine group were visualized in tissue sections of maize leaves and roots. Guo and coworkers [63] combined a laser-assisted tissue transfer (LATT) technique with the CA derivatization for imaging of up to 67 small molecule metabolites including amino acids, neurotransmitters and dipeptides, and others in brain tissue sections of rats.

With NBA and the nanosecond laser irradiation Li and coworkers [64] introduced the photoactive compound, 2nitrobenzaldehyde (NBA) in combination with the nanosecond laser irradiation at a wavelength of $355 \mathrm{~nm}$ for the derivatization of primary amine groups in peptides and proteins. The nanosecond laser irradiation enables the generation of the reactive 2-nitrosobenzoic anion $\left(\mathrm{NS}^{-}\right.$) which can rapidly react with primary amines in peptides and proteins, resulting in a mass shift of 133 Da. It was called as a nanosecond photochemical reaction (nsPCR). Base on the established microelectrophoresis and thermophoresis theory, they also proposed the on-demand matrix-removal effect for the NBA-based nsPCR strategy. The NBA-based nsPCR strategy could be applied to the brain tissue sections of the mouse brain to visualize and identify neuropeptides in the mouse brain with massive enhanced results.

With TAHS Originally, p-N,N,N-trimethylammonioanilyl Nhydroxysuccinimidyl carbamate iodide (TAHS) was synthesized by Shimbo and coworkers [94] using N,N-dimethylamino-pphenylenediamine and N,N'-dihydroxysuccinimidyl carbonate and iodomethane for the subsequent methylation and applied it for the analysis of amino acids in ESI-MS. According to this synthesis method, Toue and coworker [65] synthesized THAS for derivatization of amino acids in liver tissue sections from xenograft mouse models of human colon cancer in positive ion mode. After the derivatization with TAHS and subsequent application of 2,5-DHB matrix, the detection sensitivity of amino acids could be improved from failure in detection to easily detection. Most amino acids could be easily detected in tissue sections, especially because of the introduction of the positively charged quaternary amine group. However, some amino acids, such as lysine, histidine, threonine, aspartate, and arginine [61, 94], could hardly be detected. Further application of TAHS could be found for the analysis of phenylalanine and tyrosine [66] in liver tissue sections from a H460 human NSCLC xenograft mouse model, noradrenaline [67] in adrenal gland tissue sections from tumor patients, and glutamine [68] in tumor and benign tissue sections from patients with cholangiocarcinoma.

With DPP-TFB Conversion of the primary amino groups into charged quaternary amino groups is a good option to increase ionization efficacy. Shariatgorji and coworkers [69, 70] applied the commercially available pyrylium salts for the derivatization of primary amino groups in neurotransmitters and amino acids. They selected pyrylium salt such as 2,4diphenyl-pyranylium tetrafluoroborate (DPP-TFB), which reacts selectively and rapidly with primary amine groups under mild conditions. The resulting charged derivatization product possessed the ability of self-assisted laser desorption ionization in positive ion mode, but only with a higher concentration of DPP-TFB solution and in the presence of high amounts of metabolites. Therefore, an additional matrix such as CHCA [69] or 2,5-DHB [71-75] was applied onto brain tissue sections after derivatization, leading to the enhanced sensitivity in MALDI-MSI analysis. DPP-TFB [69-75] was applied in various animal models to localize and (semi-)quantitatively estimate changes of the metabolites such as dopamine, tyrosine, tryptamine, tyramine, phenethylamine, 3-methoxytyramine, 
Fig. 3 OTCD reactions targeting amines<smiles>NNC(=O)c1ccncc1</smiles>

isoniazid<smiles>O=C(O)/C=C/c1ccccc1</smiles><smiles>O=C(N/N=C/C=C/c1ccccc1)c1ccncc1</smiles>

trans-cinnamaldehyde<smiles>[R]N=C/C=C/c1ccc(O)c(OC)c1</smiles>

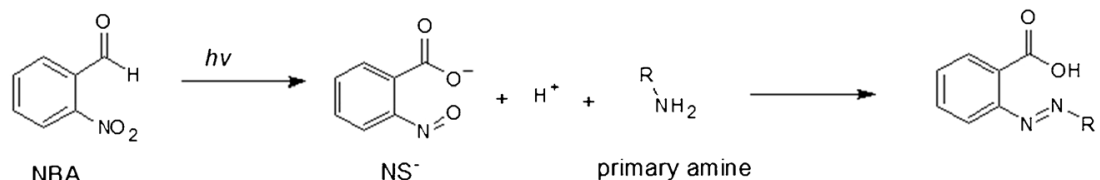

NS

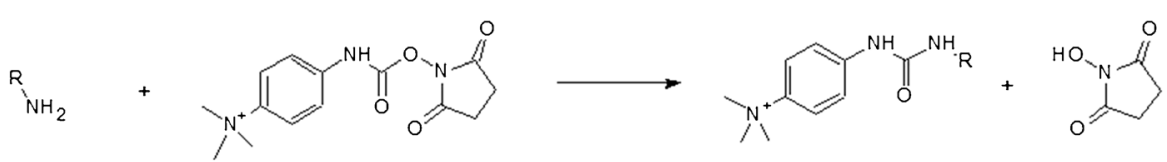

primary amine

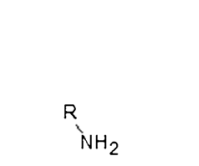

primary amine

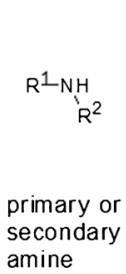

TAHS

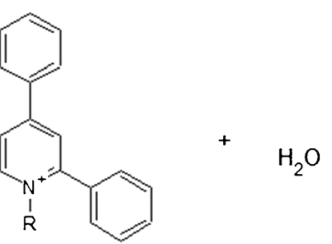

DPP

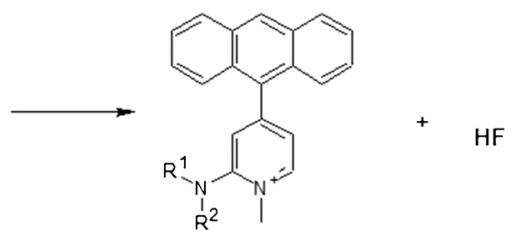

serotonin, $\gamma$-aminobutyric acid, glutamate, glycine, alanine, proline, valine, threonine, taurine, leucine, aspirate, glutamine, lysine, L-dihydroxyphenylalanine, histamine, methylhistamine, agmatine, adenine, and norepinephrine.

With FMP reagents Shariatgorji and coworkers [76] synthesized a series of pyridinium salts including 4-(10bromoanthracen-9-yl)-2-fluoro-1-methylpyridin-1-ium iodide (FMP-8), 4-(anthracen-9-yl)-2-fluoro-1-ethylpyridin-1-ium iodide (FMP-9) and 4-(anthracen-9-yl)-2-fluoro-1methylpyridin-1-ium iodide (FMP-10), which readily reacted with primary or secondary amine groups and were proven as the best candidates among them. The derivatization reaction follows the nucleophilic aromatic substitution reaction of the 2-fluoro-1-methyl pyridinium (FMP) cation with primary and secondary amine groups, which are often the functional groups of neurotransmitters and their associated metabolites from brain tissue sections. Simultaneously, the polyphenyl group in FMP reagents complies with the requirement of a MALDI matrix, which has a strong light absorption in the range of ultraviolet-visible in the solid phase. Hence, the chemically derivatized brain tissue sections can be directly measured with MALDI mass spectrometer without spraying of an additional matrix. FMP reagents were dubbed as reactive 
<smiles>[R]c1c([R])c([R])c(O)c([R])c1[R]</smiles>

phenolic hydroxyl

Catechol<smiles>[R]c1c([R])c([R])c([2H])c([R])c1[R]</smiles>
$+$

phenolic hydroxyl<smiles>[R]c1ccc(O)c(O)c1</smiles>
$+$
FMPTS<smiles>[R]c1c([R])c([R])c(Oc2cccc[n+]2C)c([R])c1[R]</smiles><smiles>C[n+]1ccc(-c2c3ccccc3cc3ccccc23)cc1F</smiles>

FMP-10<smiles>[R]c1c([R])c([R])c(Oc2cc(-c3c4ccccc4cc4ccccc34)cc[n+]2C)c([R])c1[R]</smiles>

Fig. 4 OTCD reactions targeting phenolic hydroxyl groups

matrices. The improved sensitivity after derivatization with FMP reagents enabled a comprehensive map of neurotransmitters and their associated metabolites from brain tissue sections. The ability to form small FMP derivative crystals enabled the application at a high spatial resolution of $10 \mu \mathrm{m}$. Zhang and coworkers [77] from the same laboratory applied FMP-10 to visualize the dopamine and $\gamma$-aminobutyric acid changes in parkinsonian mice lacking GPR37 in comparison with wild type mice.

\section{Target functional group: phenolic hydroxyl}

With FMP Beasley and coworkers [78] applied 2-fluoro-1methylpyridinium $p$-toluene sulfonate (FMPTS) for derivatization of the phenolic hydroxyl group of cannabinoids in human hair. After rapid derivatization reaction at room temperature and spraying of CHCA as the MALDI matrix, positively charged N-methylpyridinium derivate contributed to improved ionization efficiency of several cannabinoids and their metabolites including $\Delta^{9}$-tetrahydrocannabinol (THC) in hair, which were soaked in solutions with the respective analytes. Furthermore, THC could be visualized with FMPTS derivatization in hairs from a known cannabis consumer.

Derivatization of diol in catechol with $(\mathrm{N}-\mathrm{Me}) \mathrm{Py}{ }^{+} \mathrm{B}(\mathrm{OH})_{2}$ Kaya and coworkers [79] synthesized 4-(N-methyl)pyridinium boronic acid $\left((\mathrm{N}-\mathrm{Me}) \mathrm{Py}^{+} \mathrm{B}(\mathrm{OH})_{2}\right)$, which was applied for derivatization of catecholamines including dopamine, epinephrine, and norepinephrine in porcine adrenal gland tissue sections. Boronic acid derivative can readily react with the diol moiety of catechol (ortho isomer of dihydroxybenzene), forming five-membered boronate esters. Due to the positive charge in $(\mathrm{N}-\mathrm{Me}) \mathrm{Py}{ }^{+} \mathrm{B}(\mathrm{OH})_{2}$ and the UV-absorption ability of the derivatization products in the range of the laser wavelength of the mass spectrometer, $(\mathrm{N}-\mathrm{Me}) \mathrm{Py}^{+} \mathrm{B}(\mathrm{OH})_{2}$ was used as a reactive matrix without an additional MALDI matrix. Additionally, the unique isotopic pattern of boron-containing derivatized catecholamines assisted in data analysis.

\section{Target functional group: carbonyl}

With Girard's reagent T Cobice and coworkers [81] applied Girard's reagent T (GirT) for derivatization of 11 dehydrocorticosterone and corticosterone in rat adrenal gland and mouse brain tissue sections. The reactive hydrazine group in GirT reacts with the ketone group easily, forming hydrazine derivatives. Due to the charged quaternary amine in GirT, the resulting derivatization products (GirT-dehydrocorticosterone and GirT-corticosterone) showed enhanced ionization efficiency. Derivatization with GirT to visualize ketonecontaining analytes was demonstrated in various tissues, such as mouse testis [83, 84], cartilage [82], rat prostate [84], rat 
<smiles>[R]C([R])=O</smiles>

carbonyl Girard's reagent T<smiles>[R]C([R])=O</smiles><smiles>[R]C([R])=O</smiles>

Fig. 5 OTCD reactions targeting carbonyls

adrenal gland [85], immature $P$. vulgaris $L$. seed [86], maize root and leaf [62], human adrenal gland $[67,85]$, and rat brain [63]. In the case of structural isomers [67], tandem MS imaging was used to distinguish aldosterone from cortisol and cortisone from 18-OH-corticosterone.

DMNTH and DNPH Flinder and coworkers [80] applied different hydrazines including 2,4-dinitrophenylhydrazine (DNPH) and 4-dimethylamino-6-(4-methoxy-1-naphthyl)-1,3,5-triazine-2-hydrazine (DMNTH) on mouse lung tissue sections, which were spotted with fluticasone propionate. DNPH and DMNTH were demonstrated as reactive matrix and can be obtained by purchase and chemical synthesis in the lab, respectively. In comparison with DNPH, DMNTH showed superior results and resulted in a detection limit of $50 \mathrm{ng} / \mu \mathrm{L}$ in a humid environment at $37^{\circ} \mathrm{C}$ for $48 \mathrm{~h}$. The detection sensitivity<smiles>[R]C(=O)O</smiles>

carboxylic acid<smiles>[R]C(=O)O</smiles>

carboxylic acid<smiles>NCc1ccccn1</smiles><smiles>CCCCC(C)C</smiles>

2-picolylamine<smiles>C[N+]1(C)CCNCC1</smiles><smiles>CCC</smiles><smiles>[R]C(=O)NCc1ccccn1</smiles>

$$
+\mathrm{H}_{2} \mathrm{O}
$$<smiles>[R]C(=O)N1CC[N+](C)(C)CC1</smiles>

Fig. 6 OTCD reactions targeting carboxylic acids 


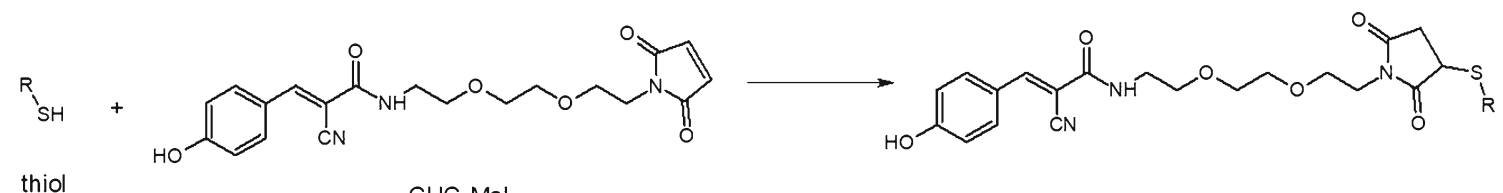

Fig. 7 OTCD reactions targeting thiols

was improved after additional application of conventional MALDI matrix CHCA.

\section{Target functional group: carboxylic acid}

With 2-picolylamine $\mathrm{Wu}$ and coworkers [87] evaluated 2picolylamine (PA), well known as derivatization reagent in solution for application as OTCD before MALDI-MSI. After activating of a carboxylic acid with 2,2-dipyridyl disulfide (DPDS) and triphenylphosphine (TPP), 2-picolylamine transferred the activated fatty acid to the stable derivatization product containing an amide bond. By using the electrospray deposition method, six fatty acids, such as docosahexaenoic acid, arachidonic acid, oleic acid, palmitoleic acid, eicosapentaenoic acid, and linoleic acid, were visualized in rat brain tissue sections with improved detection limits and decreased delocalization in positive ion mode. Thus, a spatial resolution of $20 \mu \mathrm{m}$ was reached. The approach was also applied by Dueñas and coworkers [62] for visualization of fatty acids, such as 3-maleylpyruvate, N-acetyl-L-glutamate, palmitic acid, oleic acid, stearic acid, and more other metabolites with carboxylic acid in tissue sections of maize leaves and roots.

With DMPI Wang and coworkers [88] synthesized N,Ndimethylpiperazine iodide (DMPI) using $\mathrm{CH}_{3} \mathrm{I}$ and $\mathrm{N}$ methylpiperazine. 2-(7-Azabenzotriazol-1-yl)-N,N, $N^{\prime}, N^{\prime}$ tetramethyluronium hexafluorophosphate (HATU) was used in this work to generate active esters from carboxylic acids derived from fatty acids such as C16:0 and C18:0. The active esters reacted then with DMPI, resulting in derivatized fatty acids with stable amide bonds and charged quaternary amine groups, which assisted in improved detection of fatty acid derivatives in positive ion mode. In this way, fatty acids and phospholipids could be simultaneously imaged in positive ion mode. By using optimized spraying parameters using an electrospray device and optimized derivatization conditions, this approach was proved to have advantage over the approach with 2-picolyamine [87] and applied in tissue sections from patients with thyroid cancer.

\section{Target functional group: thiol}

Fülöp and coworkers [89] designed, synthesized, and evaluated (E)-2-cyano-N-(2-(2,5-dioxo-2,5-dihydro-1H-pyrrol-1yl)ethyl)-3-(4-hydroxyphenyl)-acrylamide (CHC-Mal) as a thiol derivatization reagent. Proteins with free thiol groups, such as $\alpha$-chain and $\beta$-chain of reduced insulin, were derivatized and imaged in porcine pancreas tissue sections in positive ion mode. Besides, free thiol groups from small molecule metabolites, present in tissue or generated by spray-coated reducing agent, were derivatized and visualized in porcine liver tissue sections and tumor tissue sections of a mouse xenograft model in positive ion mode with clearly improved detection sensitivity. In this work, cysteine, cysteinylglycine, and glutathione were detectable even without application of additional 2,5-DHB matrix. In other words, CHC-Mal can be used as a reactive matrix for small thiol-containing metabolites.

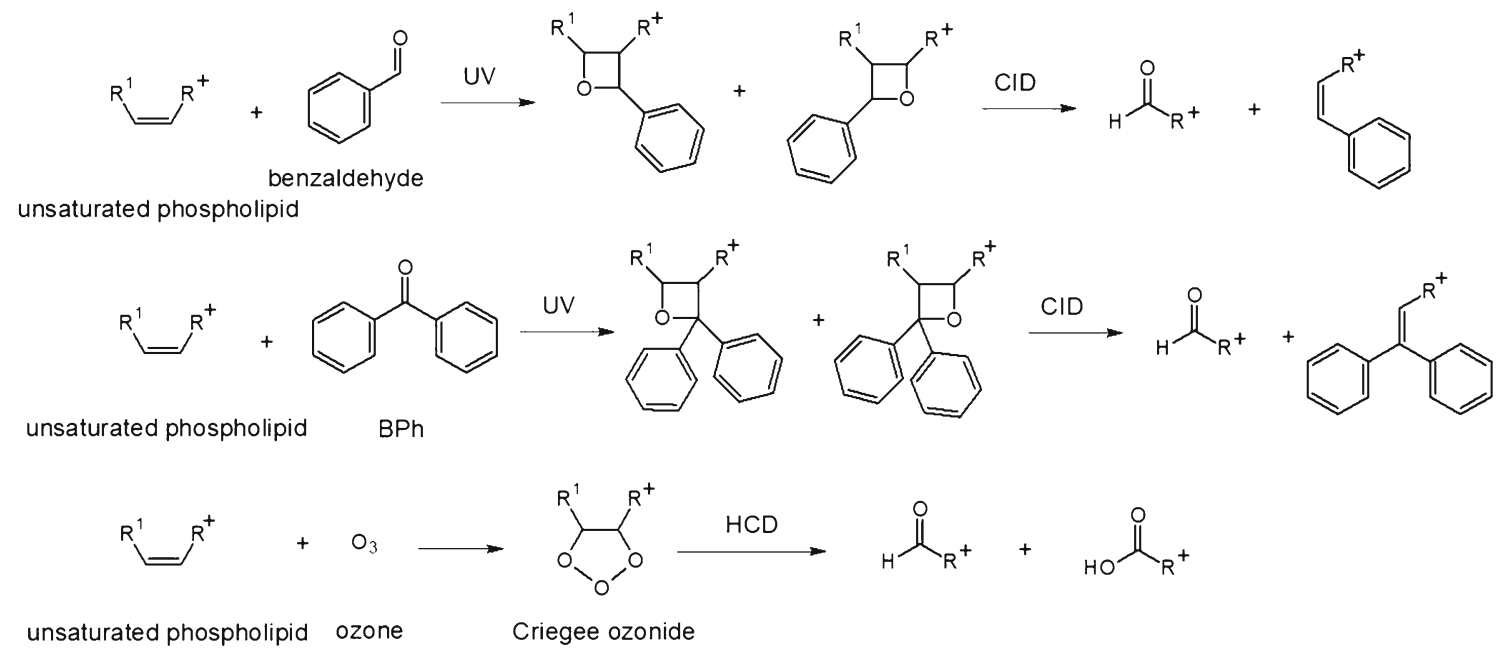

Fig. 8 OTCD reactions targeting double bonds 


\section{Target functional group: double bond}

With benzaldehyde/BPh Bednařík and coworkers [90] introduced benzaldehyde for distinguishing and imaging of lipid double bonds. A laser-induced post-ionization strategy (MALDI-2) was used for improved protonation of analytes. Benzaldehyde undergoes the Paternò-Büchi photoreaction with lipid double bonds in a reaction chamber equipped with a UV lamp. After derivatization and subsequent collisioninduced dissociation of the Paternò-Büchi photoreaction reaction products, the double bond position were verified and imaged in mouse brain tissue. Wäldchen and coworkers [91] introduced benzophenone $(\mathrm{BPh})$ as a reactive matrix for the identification of the double bond position of unsaturated phospholipids. BPh could not only act as a MALDI matrix but also react with double bond groups of unsaturated phospholipids directly after laser irradiation (330-370 nm) during measurement. Thus, no additional equipment is required for the laserinduced Paternò-Büchi photoreaction, in which $\mathrm{C}=\mathrm{C}$ double bond form a four-membered oxetane ring. Using tandem MS imaging $\left(\mathrm{MS}^{2} \mathrm{I}\right)$, spatial distributions of phospholipids with defined double bond position could be visualized in brain tissue sections of mice and tegument of S. mansoni.

With ozone Paine and coworkers [92] directly introduced ozone in the mass spectrometer, leading to ozone-induced dissociation. With this unique approach, specific lipid isomers were visualized in the rat brain. Later, Bednařík and coworkers [93] developed the approach for ozonization of unsaturated lipids under concentrated ozone atmosphere in a reaction chamber. The Criegee ozonide ions are formed after the addition of ozone to $\mathrm{C}=\mathrm{C}$ double bond in $\mathrm{PC} 34: 1$ and the subsequent rearrangement. Higher-collisional energy dissociation (HCD) of Criegee ozonide ions results in an aldehyde and carboxylic acid fragments which can indicate the $\mathrm{C}=\mathrm{C}$ double bond position. $\Delta 9$ and $\Delta 11$ isomers of PC $34: 1$ in brain tissue sections of BALB/c mice and human colon tissue sections could be visualized using this technique by $\mathrm{MS}^{2} \mathrm{I}$.

\section{Conclusion}

In this review, we have summarized recent advances in the design, discovery, and characterization of novel small organic matrices and OTCD reagents to improve MALDI-MSI performance. Although many novel matrices are still not designed for broader application, MALDI-MSI with novel matrices demonstrated to have superior results than conventional matrices in many aspects, for example, vacuum stability, detection sensitivity, molecular coverage, salt tolerance, matrix background signals, ion suppression, and crystal formation. Novel matrices have the potential to improve image quality and expand the application area of MALDI-MSI. Nevertheless, the possibility of theoretical simulations for matrix design is still missing for ionization efficiency, interaction of matrices with other competent metabolites in tissue sections, crystal formation, and other matrix performances. At the same time, OTCD processes for MALDIMSI were proven to be promising methods for visualization of poorly ionizable analytes, distinction of isomers, and characterization of isomers. Accompanying problems found in OTCD processes, such as low reaction efficiency, poor reproducibility, and additional time consumption, constrain attempts to transfer and optimize versatile in-solution chemical derivatization for OTCD for MALDI-MSI. However, OTCD processes in MALDI-MSI workflow have clear advantages in the specific detection of analytes in tissue sections. Thus, more and more attention will be paid for transferring and optimizing chemical derivatization in tissue sections, opening new possibilities for MALDI-MSI to become an indispensable tool in different research fields.

Funding Open Access funding enabled and organized by Projekt DEAL. This work was funded by the German Federal Ministry of Research (BMBF) as part of the Innovation Partnership $\mathrm{M}^{2}$ Aind, project $\mathrm{SM}^{2}$ all (03FH8I01IA) within the framework FH-Impuls (to $\mathrm{CH}$ ).

\section{Compliance with ethical standards}

Conflict of interest The authors declare that they have no conflict of interest.

Open Access This article is licensed under a Creative Commons Attribution 4.0 International License, which permits use, sharing, adaptation, distribution and reproduction in any medium or format, as long as you give appropriate credit to the original author(s) and the source, provide a link to the Creative Commons licence, and indicate if changes were made. The images or other third party material in this article are included in the article's Creative Commons licence, unless indicated otherwise in a credit line to the material. If material is not included in the article's Creative Commons licence and your intended use is not permitted by statutory regulation or exceeds the permitted use, you will need to obtain permission directly from the copyright holder. To view a copy of this licence, visit http://creativecommons.org/licenses/by/4.0/.

\section{References}

1. Ryan DJ, Spraggins JM, Caprioli RM. Protein identification strategies in MALDI imaging mass spectrometry: a brief review. Curr Opin Chem Biol. 2019;48:64-72. https://doi.org/10.1016/j.cbpa. 2018.10.023.

2. Cillero-Pastor B, Heeren RM. Matrix-assisted laser desorption ionization mass spectrometry imaging for peptide and protein analyses: a critical review of on-tissue digestion. J Proteome Res. 2014;13(2): 325-35. https://doi.org/10.1021/pr400743a.

3. ??Buck A, Walch A. In situ drug and metabolite analysis [corrected] in biological and clinical research by MALDI MS imaging. Bioanalysis. 2014;6(9):1241-53. https://doi.org/10.4155/bio.14.88.

4. Fernández JA, Ochoa B, Fresnedo O, Giralt MT, RodriguezPuertas R. Matrix-assisted laser desorption ionization imaging mass 
spectrometry in lipidomics. Anal Bioanal Chem. 2011;401(1):2951. https://doi.org/10.1007/s00216-011-4696-x.

5. ??Drake RR, West CA, Mehta AS, Angel PM. MALDI mass spectrometry imaging of N-linked glycans in tissues. Adv Exp Med Biol. 2018;1104:59-76. https://doi.org/10.1007/978-981-13-2158-0 4.

6. Schulz S, Becker M, Groseclose MR, Schadt S, Hopf C. Advanced MALDI mass spectrometry imaging in pharmaceutical research and drug development. Curr Opin Biotechnol. 2019;55:51-9. https://doi.org/10.1016/j.copbio.2018.08.003.

7. Qin L, Zhang Y, Liu Y, He H, Han M, Li Y, et al. Recent advances in matrix-assisted laser desorption/ionisation mass spectrometry imaging (MALDI-MSI) for in situ analysis of endogenous molecules in plants. Phytochem Anal. 2018;29(4):351-64. https://doi. org/10.1002/pca.2759.

8. Morisasa M, Sato T, Kimura K, Mori T, Goto-Inoue N. Application of matrix-assisted laser desorption/ionization mass spectrometry imaging for food analysis. Foods. 2019;8(12). https://doi.org/10. 3390/foods8120633.

9. Stasulli NM, Shank EA. Profiling the metabolic signals involved in chemical communication between microbes using imaging mass spectrometry. FEMS Microbiol Rev. 2016;40(6):807-13. https:// doi.org/10.1093/femsre/fuw032.

10. Ucal Y, Durer ZA, Atak H, Kadioglu E, Sahin B, Coskun A, et al. Clinical applications of MALDI imaging technologies in cancer and neurodegenerative diseases. Biochim Biophys Acta, Proteins Proteomics. 2017;1865(7):795-816. https://doi.org/10.1016/j. bbapap.2017.01.005.

11. Calvano CD, Monopoli A, Cataldi TRI, Palmisano F. MALDI matrices for low molecular weight compounds: an endless story? Anal Bioanal Chem. 2018;410(17):4015-38. https://doi.org/10.1007/ s00216-018-1014-x.

12. ??Goodwin RJA. Sample preparation for mass spectrometry imaging: small mistakes can lead to big consequences. J Proteome. 2012;75(16): 4893-911. https://doi.org/10.1016/j.jprot.2012.04.012.

13. Kaletas BK, van der Wiel IM, Stauber J, Lennard JD, Guzel C, Kros JM, et al. Sample preparation issues for tissue imaging by imaging MS. Proteomics. 2009;9(10):2622-33. https://doi.org/10.1002/ pmic. 200800364.

14. Leopold J, Popkova Y, Engel KM, Schiller J. Recent developments of useful MALDI matrices for the mass spectrometric characterization of lipids. Biomolecules. 2018;8(4). https://doi.org/10.3390/ biom8040173.

15. Hermann J, Noels H, Theelen W, Lellig M, Orth-Alampour S, Boor $\mathrm{P}$, et al. Sample preparation of formalin-fixed paraffin-embedded tissue sections for MALDI-mass spectrometry imaging. Anal Bioanal Chem. 2020;412(6):1263-75. https://doi.org/10.1007/ s00216-019-02296-x.

16. Thomas A, Chaurand P. Advances in tissue section preparation for MALDI imaging MS. Bioanalysis. 2014;6(7):967-82. https://doi. org/10.4155/bio.14.63.

17. Angel PM, Spraggins JM, Baldwin HS, Caprioli R. Enhanced sensitivity for high spatial resolution lipid analysis by negative ion mode matrix assisted laser desorption ionization imaging mass spectrometry. Anal Chem. 2012;84(3):1557-64. https://doi.org/ 10.1021/ac202383m.

18. Buchberger AR, Vu NQ, Johnson J, DeLaney K, Li L. A simple and effective sample preparation strategy for MALDI-MS imaging of neuropeptide changes in the crustacean brain due to hypoxia and hypercapnia stress. J Am Soc Mass Spectrom. 2020;31(5):105865. https://doi.org/10.1021/jasms.9b00107.

19. Shariatgorji M, Kallback P, Gustavsson L, Schintu N, Svenningsson P, Goodwin RJ, et al. Controlled-pH tissue cleanup protocol for signal enhancement of small molecule drugs analyzed by MALDI-MS imaging. Anal Chem. 2012;84(10):4603-7. https://doi.org/10.1021/ac203322q.
20. Baker TC, Han J, Borchers CH. Recent advancements in matrixassisted laser desorption/ionization mass spectrometry imaging. Curr Opin Biotechnol. 2017;43:62-9. https://doi.org/10.1016/j. copbio.2016.09.003.

21. Santos HM, Capelo JL. Probe-based chemical modulations of tissues for IMS. J Proteome. 2012;75(16):4921-30. https://doi.org/10. 1016/j.jprot.2012.05.025.

22. Gachumi G, Purves RW, Hopf C, El-Aneed A. Fast quantification without conventional chromatography, the growing power of mass spectrometry. Anal Chem. 2020;92(13):8628-37. https://doi.org/ 10.1021/acs.analchem.0c00877.

23. ??Rzagalinski I, Volmer DA. Quantification of low molecular weight compounds by MALDI imaging mass spectrometry - a tutorial review. Biochim Biophys Acta, Proteins Proteomics. 2017;1865(7):726-39. https://doi.org/10.1016/j.bbapap.2016.12.011.

24. Thomas A, Charbonneau JL, Fournaise E, Chaurand P. Sublimation of new matrix candidates for high spatial resolution imaging mass spectrometry of lipids: enhanced information in both positive and negative polarities after 1,5-diaminonapthalene deposition. Anal Chem. 2012;84(4):2048-54. https://doi.org/10.1021/ ac2033547.

25. Fülöp A, Porada MB, Marsching C, Blott H, Meyer B, Tambe S, et al. 4-Phenyl-alpha-cyanocinnamic acid amide: screening for a negative ion matrix for MALDI-MS imaging of multiple lipid classes. Anal Chem. 2013;85(19):9156-63. https://doi.org/10.1021/ ac4018154.

26. Stoyanovsky DA, Sparvero LJ, Amoscato AA, He RR, Watkins S, Pitt BR, et al. Improved spatial resolution of matrix-assisted laser desorption/ionization imaging of lipids in the brain by alkylated derivatives of 2,5-dihydroxybenzoic acid. Rapid Commun Mass Spectrom. 2014;28(5):403-12. https://doi.org/10.1002/rcm.6796.

27. Weißflog J, Svatoš A. 1,8-Di(piperidinyl)-naphthalene - rationally designed MAILD/MALDI matrix for metabolomics and imaging mass spectrometry. RSC Adv. 2016;6(79):75073-81. https://doi. org/10.1039/C6RA17237G.

28. Li N, Wang P, Liu X, Han C, Ren W, Li T, et al. Developing IR-780 as a novel matrix for enhanced MALDI MS imaging of endogenous high-molecular-weight lipids in brain tissues. Anal Chem. 2019;91(24):15873-82. https://doi.org/10.1021/acs.analchem. $9 \mathrm{~b} 04315$.

29. Yang J, Norris JL, Caprioli R. Novel vacuum stable ketone-based matrices for high spatial resolution MALDI imaging mass spectrometry. J Mass Spectrom. 2018;53(10):1005-12. https://doi.org/ $10.1002 / \mathrm{jms} .4277$.

30. Huang P, Huang CY, Lin TC, Lin LE, Yang E, Lee C, et al. Toward the rational design of universal dual polarity matrix for MALDI mass spectrometry. Anal Chem. 2020;92(10):7139-45. https://doi. org/10.1021/acs.analchem.0c00570.

31. Liu H, Zhou Y, Wang J, Xiong C, Xue J, Zhan L, et al. N-Phenyl-2naphthylamine as a novel MALDI matrix for analysis and in situ imaging of small molecules. Anal Chem. 2018;90(1):729-36. https://doi.org/10.1021/acs.analchem.7b02710.

32. Barré FPY, Claes BSR, Dewez F, Peutz-Kootstra C, MunchPetersen HF, Gronbaek K, et al. Specific lipid and metabolic profiles of R-CHOP-resistant diffuse large B-cell lymphoma elucidated by matrix-assisted laser desorption ionization mass spectrometry imaging and in vivo imaging. Anal Chem. 2018;90(24):14198206. https://doi.org/10.1021/acs.analchem.8b02910.

33. Chen R, Xu W, Xiong C, Zhou X, Xiong S, Nie Z, et al. High-salttolerance matrix for facile detection of glucose in rat brain microdialysates by MALDI mass spectrometry. Anal Chem. 2012;84(1):465-9. https://doi.org/10.1021/ac202438a.

34. Hou J, Chen S, Zhang N, Liu H, Wang J, He Q, et al. Organic salt NEDC (N-naphthylethylenediamine dihydrochloride) assisted laser desorption ionization mass spectrometry for identification of metal 
ions in real samples. Analyst. 2014;139(13):3469-75. https://doi. org/10.1039/c4an00297k.

35. Li W, Ren L, Zheng X, Liu J, Wang J, Ji T, et al. 3-O-Acetyl-11keto- beta -boswellic acid ameliorated aberrant metabolic landscape and inhibited autophagy in glioblastoma. Acta Pharm Sin B. 2020;10(2):301-12. https://doi.org/10.1016/j.apsb.2019.12.012.

36. Wang J, Qiu S, Chen S, Xiong C, Liu H, Wang J, et al. MALDITOF MS imaging of metabolites with a $\mathrm{N}-(1$-naphthyl) ethylenediamine dihydrochloride matrix and its application to colorectal cancer liver metastasis. Anal Chem. 2015;87(1):422-30. https://doi.org/10.1021/ac504294s.

37. Li B, Sun R, Gordon A, Ge J, Zhang Y, Li P, et al. 3Aminophthalhydrazide (Luminol) as a matrix for dual-polarity MALDI MS imaging. Anal Chem. 2019;91(13):8221-8. https:// doi.org/10.1021/acs.analchem.9b00803.

38. Ibrahim H, Jurcic K, Wang JS, Whitehead SN, Yeung KK. 1,6Diphenyl-1,3,5-hexatriene (DPH) as a novel matrix for MALDI MS imaging of fatty acids, phospholipids, and sulfatides in brain tissues. Anal Chem. 2017;89(23):12828-36. https://doi.org/10. 1021/acs.analchem.7b03284.

39. Sun C, Liu W, Ma S, Zhang M, Geng Y, Wang X. Development of a high-coverage matrix-assisted laser desorption/ionization mass spectrometry imaging method for visualizing the spatial dynamics of functional metabolites in Salvia miltiorrhiza Bge. J Chromatogr A. 1614;2020:460704. https://doi.org/10.1016/j.chroma.2019. 460704.

40. Sun C, Liu W, Mu Y, Wang X. 1,1'-binaphthyl-2,2'-diamine as a novel MALDI matrix to enhance the in situ imaging of metabolic heterogeneity in lung cancer. Talanta. 2020;209:120557. https:// doi.org/10.1016/j.talanta.2019.120557.

41. Liu Y, Chen L, Qin L, Han M, Li J, Luo F, et al. Enhanced in situ detection and imaging of lipids in biological tissues by using 2,3dicyanohydroquinone as a novel matrix for positive-ion MALDIMS imaging. Chem Commun (Camb). 2019;55(83):12559-62. https://doi.org/10.1039/c9cc06961e.

42. Rzagalinski I, Kovacevic B, Hainz N, Meier C, Tschernig T, Volmer DA. Toward higher sensitivity in quantitative MALDI imaging mass spectrometry of CNS drugs using a nonpolar matrix. Anal Chem. 2018;90(21):12592-600. https://doi.org/10.1021/acs. analchem. $8 \mathrm{~b} 02740$.

43. He H, Qin L, Zhang Y, Han M, Li J, Liu Y, et al. 3,4Dimethoxycinnamic acid as a novel matrix for enhanced in situ detection and imaging of low-molecular-weight compounds in biological tissues by MALDI-MSI. Anal Chem. 2019;91(4):2634 43. https://doi.org/10.1021/acs.analchem.8b03522.

44. Ulmer L, Mattay J, Torres-Garcia HG, Luftmann H. Letter: the use of 2-[(2E)-3-(4-tert-butylphenyl)-2-methylprop-2enylidene]malononitrile as a matrix for matrix-assisted laser desorption/ionization mass spectrometry. Eur J Mass Spectrom. 2000;6(1):49-52. https://doi.org/10.1255/ejms.329.

45. Fukushima T, Usui N, Santa T, Imai K. Recent progress in derivatization methods for LC and CE analysis. J Pharm Biomed Anal. 2003;30(6):1655-87. https://doi.org/10.1016/s0731-7085(02) 00511-3.

46. Marina ML, Castro-Puyana M. Derivatization in capillary electrophoresis. Methods Mol Biol. 2016;1483:37-52. https://doi.org/10. 1007/978-1-4939-6403-1 3.

47. Beale DJ, Pinu FR, Kouremenos KA, Poojary MM, Narayana VK, Boughton BA, et al. Review of recent developments in GC-MS approaches to metabolomics-based research. Metabolomics. 2018;14(11):152. https://doi.org/10.1007/s11306-018-1449-2.

48. Quirke JME, Adams CL, Van Berkel GJ. Chemical derivatization for electrospray ionization mass spectrometry. 1. Alkyl halides, alcohols, phenols, thiols, and amines. Anal Chem. 1994;66(8): 1302-15. https://doi.org/10.1021/ac00080a016.
49. Van Berkel GJ, Asano KG. Chemical derivatization for electrospray ionization mass spectrometry. 2. Aromatic and highly conjugated molecules. Anal Chem. 1994;66(13):2096-102. https:// doi.org/10.1021/ac00085a027.

50. Van Berkel GJ, Quirke JME, Adams CL. Derivatization for electrospray ionization-mass spectrometry. 4. Alkenes and alkynes. Rapid Commun Mass Spectrom. 2000;14(10):849-58. https://doi. org/10.1002/(sici)1097-0231(20000530)14:10<849::aidrcm954>3.0.co;2-t.

51. Van Berkel GJ, Quirke JME, Tigani RA, Dilley AS, Covey TR. Derivatization for electrospray ionization mass spectrometry. 3 . Electrochemically ionizable derivatives. Anal Chem. 1998;70(8): 1544-54. https://doi.org/10.1021/ac971348o.

52. Zaikin VG, Halket JM. Derivatization in mass spectrometry-8. Soft ionization mass spectrometry of small molecules. Eur. J Mass Spectrom (Chichester). 2006;12(2):79-115. https://doi.org/10. 1255/ejms. 798 .

53. Huang T, Armbruster MR, Coulton JB, Edwards JL. Chemical tagging in mass spectrometry for systems biology. Anal Chem. 2019;91(1):109-25. https://doi.org/10.1021/acs.analchem. 8 b04951.

54. Zhou X, Yang G, Guan F. Biological functions and analytical strategies of sialic acids in tumor. Cells. 2020;9(2). https://doi.org/10. 3390/cells9020273.

55. Holst S, Heijs B, de Haan N, van Zeijl RJ, Briaire-de Bruijn IH, van Pelt GW, et al. Linkage-specific in situ sialic acid derivatization for $\mathrm{N}$-glycan mass spectrometry imaging of formalin-fixed paraffinembedded tissues. Anal Chem. 2016;88(11):5904-13. https://doi. org/10.1021/acs.analchem.6b00819.

56. Claes BSR, Takeo E, Fukusaki E, Shimma S, Heeren RMA. Imaging isomers on a biological surface: a review. Mass Spectrom (Tokyo). 2019;8(1):A0078. https://doi.org/10.5702/ massspectrometry.A0078.

57. Gemperline E, Chen B, Li L. Challenges and recent advances in mass spectrometric imaging of neurotransmitters. Bioanalysis. 2014;6(4):525-40. https://doi.org/10.4155/bio.13.341.

58. Sugiura Y, Honda K, Suematsu M. Development of an imaging mass spectrometry technique for visualizing localized cellular signaling mediators in tissues. Mass Spectrom (Tokyo). 2015;4(1): A0040. https://doi.org/10.5702/massspectrometry.A0040.

59. Manier ML, Reyzer ML, Goh A, Dartois V, Via LE, Barry CE 3rd, et al. Reagent precoated targets for rapid in-tissue derivatization of the anti-tuberculosis drug isoniazid followed by MALDI imaging mass spectrometry. J Am Soc Mass Spectrom. 2011;22(8):140919. https://doi.org/10.1007/s13361-011-0150-8.

60. Manier ML, Spraggins JM, Reyzer ML, Norris JL, Caprioli RM. A derivatization and validation strategy for determining the spatial localization of endogenous amine metabolites in tissues using MALDI imaging mass spectrometry. J Mass Spectrom. 2014;49(8):665-73. https://doi.org/10.1002/jms.3411.

61. Esteve C, Tolner EA, Shyti R, van den Maagdenberg AM, McDonnell LA. Mass spectrometry imaging of amino neurotransmitters: a comparison of derivatization methods and application in mouse brain tissue. Metabolomics. 2016;12:30. https://doi.org/10. 1007/s11306-015-0926-0.

62. Dueñas ME, Larson EA, Lee YJ. Toward mass spectrometry imaging in the metabolomics scale: increasing metabolic coverage through multiple on-tissue chemical modifications. Front Plant Sci. 2019;10:860. https://doi.org/10.3389/fpls.2019.00860.

63. Guo S, Tang W, Hu Y, Chen Y, Gordon A, Li B, et al. Enhancement of on-tissue chemical derivatization by laserassisted tissue transfer for MALDI MS imaging. Anal Chem. 2020;92(1):1431-8. https://doi.org/10.1021/acs.analchem. $9 \mathrm{~b} 04618$.

64. Li G, Ma F, Cao Q, Zheng Z, DeLaney K, Liu R, et al. Nanosecond photochemically promoted click chemistry for enhanced 
neuropeptide visualization and rapid protein labeling. Nat Commun. 2019;10(1):4697. https://doi.org/10.1038/s41467-01912548-0.

65. Toue S, Sugiura Y, Kubo A, Ohmura M, Karakawa S, Mizukoshi $\mathrm{T}$, et al. Microscopic imaging mass spectrometry assisted by ontissue chemical derivatization for visualizing multiple amino acids in human colon cancer xenografts. Proteomics. 2014;14(7-8):810 9. https://doi.org/10.1002/pmic.201300041.

66. Arts M, Soons Z, Ellis SR, Pierzchalski KA, Balluff B, Eijkel GB, et al. Detection of localized hepatocellular amino acid kinetics by using mass spectrometry imaging of stable isotopes. Angew Chem Int Ed Engl. 2017;56(25):7146-50. https://doi.org/10.1002/anie. 201702669.

67. Takeo E, Sugiura Y, Uemura T, Nishimoto K, Yasuda M, Sugiyama E, et al. Tandem mass spectrometry imaging reveals distinct accumulation patterns of steroid structural isomers in human adrenal glands. Anal Chem. 2019;91(14):8918-25. https://doi. org/10.1021/acs.analchem.9b00619.

68. Wappler J, Arts M, Roth A, Heeren RMA, Peter Neumann U, Olde Damink SW, et al. Glutamine deprivation counteracts hypoxiainduced chemoresistance. Neoplasia. 2020;22(1):22-32. https:// doi.org/10.1016/j.neo.2019.10.004

69. Shariatgorji M, Nilsson A, Goodwin RJ, Kallback P, Schintu N, Zhang X, et al. Direct targeted quantitative molecular imaging of neurotransmitters in brain tissue sections. Neuron. 2014;84(4):697707. https://doi.org/10.1016/j.neuron.2014.10.011.

70. Shariatgorji M, Nilsson A, Kallback P, Karlsson O, Zhang X, Svenningsson $\mathrm{P}$, et al. Pyrylium salts as reactive matrices for MALDI-MS imaging of biologically active primary amines. J Am Soc Mass Spectrom. 2015;26(6):934-9. https://doi.org/10.1007/ s13361-015-1119-9.

71. Eto F, Sato S, Setou M, Yao I. Region-specific effects of scrapper on the abundance of glutamate and gamma-aminobutyric acid in the mouse brain. Sci Rep. 2020;10(1):7435. https://doi.org/10.1038/ s41598-020-64277-w.

72. Sugiyama E, Kondo T, Kuzumaki N, Honda K, Yamanaka A, Narita M, et al. Mechanical allodynia induced by optogenetic sensory nerve excitation activates dopamine signaling and metabolism in medial nucleus accumbens. Neurochem Int. 2019;129:104494. https://doi.org/10.1016/j.neuint.2019.104494.

73. Sugiyama E, Guerrini MM, Honda K, Hattori Y, Abe M, Kallback $\mathrm{P}$, et al. Detection of a high-turnover serotonin circuit in the mouse brain using mass spectrometry imaging. iScience. 2019;20:359-72. https://doi.org/10.1016/j.isci.2019.09.036.

74. Dilillo M, Ait-Belkacem R, Esteve C, Pellegrini D, Nicolardi S, Costa M, et al. Ultra-high mass resolution MALDI imaging mass spectrometry of proteins and metabolites in a mouse model of glioblastoma. Sci Rep. 2017;7(1):603. https://doi.org/10.1038/s41598017-00703-w.

75. Cao Q, Wang Y, Chen B, Ma F, Hao L, Li G, et al. Visualization and identification of neurotransmitters in crustacean brain via multifaceted mass spectrometric approaches. ACS Chem Neurosci. 2019;10(3):1222-9. https://doi.org/10.1021/acschemneuro. 8 b00730.

76. Shariatgorji M, Nilsson A, Fridjonsdottir E, Vallianatou T, Kallback P, Katan L, et al. Comprehensive mapping of neurotransmitter networks by MALDI-MS imaging. Nat Methods. 2019;16(10):1021-8. https://doi.org/10.1038/s41592-019-0551-3.

77. Zhang X, Mantas I, Fridjonsdottir E, Andren PE, Chergui K, Svenningsson P. Deficits in motor performance, neurotransmitters and synaptic plasticity in elderly and experimental parkinsonian mice lacking GPR37. Front Aging Neurosci. 2020;12:84. https:// doi.org/10.3389/fnagi.2020.00084.

78. Beasley E, Francese S, Bassindale T. Detection and mapping of cannabinoids in single hair samples through rapid derivatization and matrix-assisted laser desorption ionization mass spectrometry.
Anal Chem. 2016;88(20):10328-34. https://doi.org/10.1021/acs. analchem.6b03551.

79. Kaya I, Brulls SM, Dunevall J, Jennische E, Lange S, Martensson J, et al. On-tissue chemical derivatization of catecholamines using 4(N-methyl)pyridinium boronic acid for ToF-SIMS and LDI-ToF mass spectrometry imaging. Anal Chem. 2018;90(22):13580-90. https://doi.org/10.1021/acs.analchem.8b03746.

80. Flinders B, Morrell J, Marshall PS, Ranshaw LE, Clench MR. The use of hydrazine-based derivatization reagents for improved sensitivity and detection of carbonyl containing compounds using MALDI-MSI. Anal Bioanal Chem. 2015;407(8):2085-94. https:// doi.org/10.1007/s00216-014-8223-8.

81. Cobice DF, Mackay CL, Goodwin RJ, McBride A, LangridgeSmith PR, Webster SP, et al. Mass spectrometry imaging for dissecting steroid intracrinology within target tissues. Anal Chem. 2013;85(23):11576-84. https://doi.org/10.1021/ac402777k.

82. Barré FP, Flinders B, Garcia JP, Jansen I, Huizing LR, Porta T, et al. Derivatization strategies for the detection of triamcinolone acetonide in cartilage by using matrix-assisted laser desorption/ ionization mass spectrometry imaging. Anal Chem. 2016;88(24): 12051-9. https://doi.org/10.1021/acs.analchem.6b02491.

83. ??Shimma S, Kumada HO, Taniguchi H, Konno A, Yao I, Furuta K, et al. Microscopic visualization of testosterone in mouse testis by use of imaging mass spectrometry. Anal Bioanal Chem. 2016;408(27):7607-15. https://doi.org/10. 1007/s00216-016-9594-9.

84. Cobice DF, Livingstone DE, Mackay CL, Goodwin RJ, Smith LB, Walker BR, et al. Spatial localization and quantitation of androgens in mouse testis by mass spectrometry imaging. Anal Chem. 2016;88(21):10362-7. https://doi.org/10.1021/acs.analchem. $6 \mathrm{~b} 02242$.

85. Sugiura Y, Takeo E, Shimma S, Yokota M, Higashi T, Seki T, et al. Aldosterone and 18-oxocortisol coaccumulation in aldosteroneproducing lesions. Hypertension. 2018;72(6):1345-54. https://doi. org/10.1161/HYPERTENSIONAHA.118.11243.

86. Enomoto H, Sensu T, Yumoto E, Yokota T, Yamane H. Derivatization for detection of abscisic acid and 12-oxophytodienoic acid using matrix-assisted laser desorption/ ionization imaging mass spectrometry. Rapid Commun Mass Spectrom. 2018;32(17):1565-72. https://doi.org/10.1002/rcm. 8200.

87. Wu Q, Comi TJ, Li B, Rubakhin SS, Sweedler JV. On-tissue derivatization via electrospray deposition for matrix-assisted laser desorption/ionization mass spectrometry imaging of endogenous fatty acids in rat brain tissues. Anal Chem. 2016;88(11):5988-95. https://doi.org/10.1021/acs.analchem.6b01021.

88. Wang SS, Wang YJ, Zhang J, Sun TQ, Guo YL. Derivatization strategy for simultaneous molecular imaging of phospholipids and low-abundance free fatty acids in thyroid cancer tissue sections. Anal Chem. 2019;91(6):4070-6. https://doi.org/10.1021/acs. analchem.8b05680.

89. Fülöp A, Bausbacher T, Rizzo S, Zhou Q, Gillandt H, Hopf C, et al. New derivatization reagent for detection of free thiol-groups in metabolites and proteins in matrix-assisted laser desorption/ ionization mass spectrometry imaging. Anal Chem. 2020;92(9): 6224-8. https://doi.org/10.1021/acs.analchem.9b05630.

90. Bednařík A, Bolsker S, Soltwisch J, Dreisewerd K. An on-tissue Paternò-Büchi reaction for localization of carbon-carbon double bonds in phospholipids and glycolipids by matrix-assisted laserdesorption-ionization mass-spectrometry imaging. Angew Chem Int Ed Engl. 2018;57(37):12092-6. https://doi.org/10.1002/anie. 201806635.

91. Wäldchen F, Spengler B, Heiles S. Reactive matrix-assisted laser desorption/ionization mass spectrometry imaging using an intrinsically photoreactive Paterno-Buchi matrix for double-bond 
localization in isomeric phospholipids. J Am Chem Soc. 2019;141(30):11816-20. https://doi.org/10.1021/jacs.9b05868.

92. Paine MRL, Poad BLJ, Eijkel GB, Marshall DL, Blanksby SJ, Heeren RMA, et al. Mass spectrometry imaging with isomeric resolution enabled by ozone-induced dissociation. Angew Chem Int Ed Engl. 2018;57(33):10530-4. https://doi.org/10.1002/anie. 201802937.

93. Bednařík A, Preisler J, Bezdekova D, Machalkova M, Hendrych M, Navratilova J, et al. Ozonization of tissue sections for MALDI MS imaging of carbon-carbon double bond positional isomers of phospholipids. Anal Chem. 2020;92(9):6245-50. https://doi.org/ 10.1021/acs.analchem.0c00641.

94. Shimbo K, Yahashi A, Hirayama K, Nakazawa M, Miyano H. Multifunctional and highly sensitive precolumn reagents for amino acids in liquid chromatography/tandem mass spectrometry. Anal Chem. 2009;81(13):5172-9. https://doi.org/10.1021/ac900470w.

Publisher's note Springer Nature remains neutral with regard to jurisdictional claims in published maps and institutional affiliations. 